\title{
Management \\ of irritable bowel syndrome: Novel approaches to the pharmacology of gut motility
}

\author{
Carmelo Scarpignato MD DSc PharmD FCP FACG ${ }^{1,2}$, Iva Pelosini MS ${ }^{2}$
}

C Scarpignato, I Pelosini. Management of irritable bowel syndrome: Novel approaches to the pharmacology of gut motility. Can J Gastroenterol 1999;13(Suppl A):50A-65A. Although it is unclear to what extent irritable bowel syndrome (IBS) symptoms represent a normal perception of abnormal function or an abnormal perception of normal function, many believe that IBS constitutes the clinical expression of an underlying motility disorder, affecting primarily the mid- and lower gut. Indeed, transit and contractile abnormalities have been demonstrated with sophisticated techniques in a subset of patients with IBS. As a consequence, drugs affecting gastrointestinal (GI) motility have been widely employed with the aim of correcting the major IBS manifestations, ie, pain and altered bowel function.

Unfortunately, no single drug has proven to be effective in treating IBS symptom complex. In addition, the use of some medications has often been associated with unpleasant side effects. Therefore, the search for a truly effective and safe drug to control motility disturbances in IBS continues. Several classes of drugs look promising and are under evaluation. Among the motor-inhibiting drugs, gut selective muscarinic antagonists (such as zamifenacin and darifenacin), neurokinin ${ }_{2}$ antagonists (such as MEN-10627 and MEN-11420), beta ${ }_{3}$-adrenoreceptor agonists (eg, SR-58611A) and GI-selective calcium channel blockers (eg, pinaverium bromide and octylonium) are able to decrease painful contractile activity in the gut (antispasmodic effect), without significantly affecting other body functions.

Novel mechanisms to stimulate GI motility and transit include blockade of cholecystokinin $(\mathrm{CCK})_{\mathrm{A}}$ receptors and stimulation of motilin receptors. Loxiglumide (and its dextroisomer, dexloxiglumide) is the only $\mathrm{CCK}_{\mathrm{A}}$ receptor antagonist that is being eval- uated clinically. This drug accelerates gastric emptying and colonic transit, thereby increasing the number of bowel movements in patients with chronic constipation. It is also able to reduce visceral perception. Erythromycin and related 14-member macrolide compounds inhibit the binding of motilin to its receptors on GI smooth muscle and, therefore, act as motilin agonists. This antibiotic accelerates gastric emptying and shortens orocecal transit time. In the large bowel a significant decrease in transit is observed only in the right colon, which suggests a shift in fecal distribution. Several 'motilinomimetics' have been synthesized. Their development depends on the lack of antimicrobial activity and the absence of fading of the prokinetic effect during prolonged administration. 5-hydroxytryptamine $(5-\mathrm{HT})_{4}$ agonists with significant pharmacological effects on the mid- and distal gut (such as prucalopride and tegaserod) are available for human use. These 'enterokinetic' compounds are useful for treating constipation-predominant IBS patients. $5-\mathrm{HT}_{3}$ receptor antagonists also possess a number of interesting pharmacological properties that may make them suitable for treatment of IBS. Besides decreasing colonic sensitivity to distension, these drugs prolong intestinal transit and may be particularly useful in diarrhea-predominant IBS. Finally, when administered in small pulsed doses, octreotide, besides reducing the perception of rectal distension, accelerates intestinal transit, although other evidence disputes such an effect. (Pour le résumé, voir page 51A).

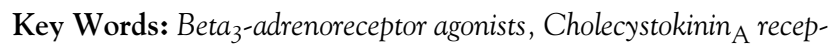
tor antagonists, 5-Hydroxytryptamine ${ }_{4}$ receptor agonists, Gastrointestinal-selective calcium channel blockers, Motilin receptor agonists, Muscarinic antagonists, Neurokinin 2 -antagonist

\footnotetext{
${ }^{1}$ Department of Gastroenterology and Hepatology, Faculty of Medicine, University of Nantes, Nantes, France; and ${ }^{2}$ Laboratory of Clinical Pharmacology, Department of Internal Medicine, School of Medicine and Dentistry, University of Parma, Parma, Italy

Correspondence and reprints: Professor C Scarpignato, Laboratory of Clinical Pharmacology, Department of Internal Medicine, Maggiore University Hospital, 43100 Parma, Italy. Telephone 39-0521-903863, fax 39-0521-903864, e-mail scarpi@tin.it
} 


\section{COPYRIGHT PULSUS GROUP ING, DONOT COPY}

\section{Le traitement du syndrome du côlon irritable : Nouvelles approches pharmacologiques de la dysmotilité}

RÉSUMÉ : On ignore dans quelle mesure précise les symptômes du syndrome du côlon irritable (SCI) représentent une perception normale d'une fonction anormale ou une perception anormale d'une fonction normale, mais nombreux sont ceux pour qui le SCI est l'expression clinique d'une dysmotilité sous-jacente, affectant surtout les portions moyennes et distales de l'intestin. En effet les anomalies de transit et de contractilité ont été décrites à l'aide de techniques de pointe chez une sous-série de patients atteints de SCI. Par conséquent, les médicaments qui influent sur la motilité gastro-intestinale (GI) ont été largement utilisés dans le but de soulager les principaux symptômes du SCI, soit la douleur et les anomalies de la fonction intestinale. Malheureusement, aucun médicament ne s'est révélé apte à traiter à lui seul les manifestations de ce syndrome. De plus, l'emploi de certains médicaments a souvent été associé à des réactions indésirables. C'est pourquoi on continue de chercher un médicament vraiment efficace et sûr pour maîtriser les problèmes associés à la dysmotilité dans le SCI. Plusieurs classes de médicaments semblent prometteuses et sont en cours d'évaluation. Parmi les médicaments exerçant un effet inhibiteur sur la motricité, mentionnons les antagonistes muscariniques sélectifs à l'endroit de l'intestin (comme la zamifenacine et la darifenacine), les antagonistes de la neurokinine ${ }_{2}$ (comme le MEN-10627 et le MEN-11420), les agonistes des bêta 3 -adrénorécepteurs (p. ex., SR58611A) et les anticalciques GI-sélectifs (p. ex., le bromure de pinaverium et l'octylonium) qui peuvent atténuer l'activité contractile douloureuse dans l'intestin (effet antispasmodique), sans affecter significativement les autres fonctions de l'organisme. Les nouveaux mécanismes servant à stimuler la motricité et le transit GI sont le blocage des récepteurs la cholécystokinine $(\mathrm{CCK})_{\mathrm{A}}$ et la stimulation des récepteurs de la motiline. Le loxiglumide (et son dextro-isomère, le dexloxiglumide) est le seul antagoniste des $\mathrm{CCK}_{\mathrm{A}}$ évalué en clinique. Ce médicament accélère la vidange gastrique et le transit colique, ce qui accroît le nombre de défécations chez les patients souffrant de constipation chronique. Il peut également atténuer la perception viscérale. L'érythromycine et les substances de types macrolide à 14 éléments apparentés inhibent la fixation de la motiline à ses récepteurs sur le muscle lisse GI et agissent ainsi comme des antagonistes de la motiline. Cet antibiotique accélère la vidange gastrique et abrège la durée du transit orocaecal. Dans le côlon, un ralentissement significatif du transit s'observe seulement au côlon ascendant, ce qui suggère un déplacement de la distribution fécale. Plusieurs motilinomimétiques ont été mis au point. Leur développement dépend de l'absence d'activité antimicrobienne et d'atténuation de l'effet procinétique durant une administration prolongée. Il existe des traitements à base d'agonistes de la 5 -hydroxytryptamine $\left(5-\mathrm{HT}_{4}\right)$ produisant des effets significatifs sur les portions moyennes et distales de l'intestin (comme le prucalopride et le tegaserod). Ces molécules entérocinétiques sont utiles pour le traitement de la constipation chez les patients atteints de SCI dont c'est le malaise dominant. Les antagonistes des récepteurs de la $5-\mathrm{HT}_{3}$ possèdent aussi d'intéressantes propriétés pharmacocinétiques qui en font un traitement adéquat pour le SCI. En plus de réduire la sensibilité colique à la distension, ces médicaments prolongent le transit intestinal et peuvent être particulièrement utiles en présence d'un SCI caractérisé par de la diarrhée. Finalement, lorsqu'on les administre en petites doses pulsées, les octréotides, en plus de réduire la perception de distension rectale, accélèrent le transit intestinal, mais cette observation ne semble pas faire l'unanimité.
$\mathrm{T}$ he irritable bowel syndrome (IBS) is a biopsychosocial disorder in which altered motility or sensation in the small bowel or colon is modulated by input from the central nervous system, including the higher centres.

The abnormal motor functions of the digestive tract in IBS patients have been recognized for several decades (1). More recently, markers of altered motor function have been described in small bowel motility studies of patients with IBS. Horowitz and Farrar (2) were the first to observe clustered contractions during episodes of abdominal colic. Later on, Kellow and Phillips (3) confirmed this finding and identified the coincidence of painful cramps with the passage of high-amplitude pressure waves through the ileocecal region, suggesting that altered sensation is an important cofactor of the clustered activity. Gorard et al (4), using ambulatory small bowel manometry, showed no increased frequency of clusters in patients with IBS with diarrhea compared with healthy controls. Patients with diarrhea-predominant IBS have more jejunal contractions during phase II and postprandially than healthy subjects. Colons of patients with diarrhea-predominant IBS have a greater number of fast contractions (5) and propagated contractions (6). In contrast, patients with constipation-predominant IBS have fewer high-amplitude propagated contractions (7).

Along with abnormal motility patterns, transit times are altered in patients with IBS. Cann et al (8) showed that patients with IBS and diarrhea have accelerated whole gut transit times; in some patients, fast orocecal transit was also observed. More recently, Vassallo et al (9) demonstrated that transit through the ascending and transverse colon is accelerated in patients with diarrhea-predominant IBS, and is positively correlated with stool weight. Conversely, patients with idiopathic constipation, normal colonic diameter, and normal anorectal and pelvic floor function have overall delays in colonic transit with predominant slowing of proximal colonic emptying (10). Reviews by Drossman et al (11) and Müller-Lissner et al (12) provide a detailed description of small bowel, colonic and rectal motility in the different subgroups (ie, constipation-predominant, diarrhea-predominant and pain-predominant).

Although it is unclear to what extent IBS symptoms represent a normal perception of abnormal function or an abnormal perception of normal function, many believe that IBS constitutes the clinical expression of an underlying motility disorder, affecting primarily the mid- and lower gut. Indeed, transit and contractile abnormalities have been demonstrated with sophisticated techniques in a subset of patients with IBS. As a consequence, drugs affecting gastrointestinal (GI) motility have been widely employed with the aim of correcting the major IBS manifestations, ie, pain and altered bowel function.

\section{AVAILABLE DRUGS}

Long term studies of IBS show that symptoms may disappear with time and that the survival of these long suffering patients is unimpaired. In a chronic, benign condition, often 


\section{COPYRIGHT PULSUS GROUP INC, DO NOT COPY}

beginning in youth and affecting nearly $15 \%$ of the population, drugs should be avoided when possible.

A variety of pharmacological agents have been used for the treatment of IBS. Despite their widespread use, it has been difficult to demonstrate their efficacy in controlled clinical trials. Indeed, Klein (13) reviewed 43 randomized, double-blind, placebo controlled IBS treatment trials published from 1966 to 1988 and found them all to be flawed. He concluded that "not a single study offers convincing evidence that any therapy is effective in treating the IBS symptom complex". A number of problems in the design of IBS trials make any valid conclusions difficult and render any comparisons of trials almost impossible $(13,14)$. Although an international working team (15) agreed with and updated Klein's conclusions and set out suggested standards for clinical trials, studies subsequent to Klein's critique are still inadequate.

In light of the overwhelming deficiencies in IBS trials, one might conclude that drug therapy has no role in the treatment of IBS. However, such a conclusion would be spurious. While no drug is of proven benefit for IBS, the lack of demonstrable drug efficacy may reflect more the inadequacy of the clinical trials than the drug itself. Future trials should endeavour to overcome these shortcomings by paying careful attention to the study population, the study design, the measurements of efficacy and the statistical analysis.

Patients with IBS often have a variety of symptoms such as diarrhea, constipation, abdominal pain or bloating. In approaching the medical treatment of IBS, however, it is often helpful to focus on the predominant complaint (16); for most patients, this is abdominal pain, constipation or diarrhea.

A variety of antispasmodic medications are available for the treatment of the crampy abdominal pain associated with IBS. These belong to the so-called smooth muscle relaxants and include antimuscarinic compounds and myolitic drugs. Despite the widespread use of these drugs in IBS, no well controlled trials have demonstrated the efficacy of these agents; both Klein (13) and Ivey (17) concluded that the benefit of these drugs in IBS is unproven. This lack of success is most likely due to the lack of a clear correlation between increased GI tract motility and pain symptoms, and to the likelihood that symptoms are due to a sensory defect rather than to hypercontractility. Nevertheless, a meta-analysis (18) examining randomized, controlled trials of smooth muscle relaxants detected a significant, although modest (ie, $19 \%$ ), benefit of three such agents (cimetropium bromide, octylonium bromide and dicyclomine bromide) in the relief of pain.

More recently, attention has focused on the calcium channel blockers in IBS therapy. These drugs have been shown to decrease postprandial colonic motility and neostigmine-induced spasm in IBS patients (19). Unfortunately, there are insufficient trial data pertaining to the utility of these agents in treating patients with IBS. In general, potential cardiovascular side effects hamper enthusiasm for the use of these agents, and their tendency to constipate may exacerbate this problem in patients with constipation-predominant IBS. However, a small double-blind trial (20) showed no significant improvement in IBS patients treated with nifedipine compared with those treated with placebo.

The tricyclic antidepressants (eg, amitriptyline, imipramine and doxepin) and, more recently, the serotonin reuptake inhibitors (eg, fluoxetine, paroxetine and sertraline) have a role in controlling pain via central analgesia (21), as well as the associated depressive symptoms. These drugs should, therefore, be considered for unremitting pain and impaired daily function, with or without coexistent symptoms of major or atypical (masked) depression. In contrast to antidepressants, anxiolytics, such as benzodiazepines, do not relieve pain and may lead to dependence. Even with doses lower than the conventional ones, complete remission or improvement of bowel symptoms is observed (22), provided that the treatment period is sufficiently long (ie, at least three months). Tricyclic antidepressants may cause or aggravate constipation in patients with IBS because of their anticholinergic side effects, and are thus best avoided in the subgroup with pain and constipation.

Although dietary fibre increases stool weight and decreases colonic transit time in both normal subjects and IBS patients (23), and dietary fibre supplementation is first attempted, patients for whom constipation is a predominant problem may benefit from prokinetic compounds. A true prokinetic agent is one that not only increases GI motility but also improves the coordination of the various motor functions and accelerates transit through the esophagus, stomach and intestine. Among the existing prokinetic compounds, dopamine antagonists and cholinomimetic drugs should be distinguished (24). Because compounds endowed with dopamine antagonism have the disadvantage of causing neuroendocrine side effects and/or extrapyramidal dyskinetic reactions (seen especially after metoclopramide administration), the recently developed noncholinergic nonantidopaminergic compound, cisapride, seems to be the most effective. Its main mechanism of action is considered to be the stimulation of myenteric cholinergic nerves with consequent increase of acetylcholine (Ach) release. Schuurkes (25) showed the effects of cisapride to be mediated by 5 -hydroxytryptamine $(5-\mathrm{HT})_{4}$ receptor stimulation in guinea pig ileum and colon.

Cisapride has been demonstrated to enhance small and large bowel transit in healthy subjects (26). These effects translate into an increased frequency of bowel movements in normal subjects as well as those with constipation. In patients with constipation-predominant IBS, Passaretti et al (27) showed a decreased whole-gut transit time after six weeks of therapy with cisapride $10 \mathrm{mg}$ tid, which correlated with an increase in stool frequency and a decrease in abdominal pain. In the first placebo controlled study with cisapride, Van Outryve et al (28) found a significant improvement in stool frequency and consistency, abdominal pain and severity, and abdominal distension in cisapride-treated patients. A flaw of this study is that symptoms and stool patterns were 
COPYRIGHT PULSUS GROU

assessed with monthly interviews without the use of daily diaries, subjecting the results to recall bias. Nevertheless, this encouraging report suggested that further trials with cisapride be udertaken in patients with constipation-predominant IBS. One such trial, however, did not show any benefit of the drug over placebo in the treatment of constipation and abdominal discomfort in IBS patients (29).

There are very few indications for the use of laxatives in clinical practice. Chronic constipation is not one of them. As a general rule, laxatives should be reserved for severe constipation, and are best avoided in patients with alternating constipation and diarrhea, for obvious reasons. When using these agents, the smallest dose for the shortest period of time is prudent. Hyperosmotic laxatives such as oral lactulose or glycerin suppositories are reasonable choices given their relatively quick onset of action. However, lactulose may worsen bloating and flatulence, and electrolyte imbalance may occur with chronic use. Stool-softeners are safe agents, but have a slower onset of action.

In diarrhea-predominant IBS, drugs that slow transit seem to be a logical choice of therapy, the most popular being the opiate antagonist loperamide. This drug appears to decrease propulsive activity by causing contraction of the circular smooth muscle, through stimulation of mu receptors (30). This drug slows small intestinal transit time in healthy subjects and IBS patients in a dose-dependent manner (30).

A double-blind crossover trial showed that loperamide may benefit patients with diarrhea by reducing stool frequency, and alleviating urgency and incontinence (31). Two further studies proved the drug to be capable of reducing abdominal pain $(32,33)$. If patients are allowed to find their optimal dose and then take the drug on a continuous basis, it can be very effective without necessarily constipating the patient.

Highly specific $5-\mathrm{HT}_{3}$ receptor antagonists have been developed that appear to slow colonic transit in normal subjects (34). 5- $\mathrm{HT}_{3}$ receptors may also modulate visceral afferent sensation; antagonists to these receptors have been demonstrated to reduce the visceral pain response in both animals and humans (reviewed in 35). With these properties in mind, the use of serotonin $5-\mathrm{HT}_{3}$ antagonists has been studied in patients with diarrhea-predominant IBS - both to reduce diarrhea and to dampen the heightened visceral nociception that is commonly noted in these patients.

Two studies to date $(36,37)$ have looked at the role of $5-\mathrm{HT}_{3}$ antagonists in diarrhea-predominant IBS. Both demonstrated a significant improvement in stool consistency (but not stool weight), without a significant effect on abdominal pain. Contrary to expectations, colonic transit time was not increased by ondansetron treatment.

The $5-\mathrm{HT}_{3}$ antagonists are another in a long line of drugs that have been touted as potential breakthroughs in the treatment of IBS. However, none of the other 'magic bullets' has withstood the objective scrutiny of controlled clinical trial testing, and it is doubtful that these agents will be any different. It must be emphasized, however, that pharmacological treatment may be helpful on an intermittent or
INC. " DO NOT COPY

chronic basis in the treatment of specific severe symptoms. The overwhelming majority of patients respond to education, reassurance and a stable therapeutic relationship with the primary care provider.

\section{NOVEL PHARMACOLOGICAL APPROACHES Motor-inhibiting drugs}

Despite the widespread use of antispasmodics in IBS, these medications have met with mixed results in placebo controlled trials. This limited benefit is due not only to the lack of a clear correlation between increased GI tract motility and pain symptoms, but also to the untoward effects often associated with long term use. Therefore, the search for a truly effective and safe drug to control motility disturbances in IBS continues.

Several classes of drugs look promising and are under evaluation. Among the motor-inhibiting drugs, gutselective muscarinic antagonists, neurokinin $(\mathrm{NK})_{2}$-antagonists, beta 3 -adrenoreceptor agonists and GI-selective calcium channel blockers are able to decrease painful contractile activity in the gut (antispasmodic effect), without significantly affecting other body functions.

Gut-selective muscarinic antagonists: The excitatory actions (motility and secretion) of Ach on the alimentary tract are well established. Muscarinic receptors are present in smooth muscle from myenteric plexus, and longitudinal and circular muscle from the esophagus to the bowel, with the stomach and the colon possessing the highest number of ${ }^{3} \mathrm{H}$-quinucliolinyl benzilate binding sites (38). Muscarinic receptors are heterogeneous and have been classified using pharmacological techniques into $M_{1}, M_{2}, M_{3}$ and $M_{4}$, and using genomic cloning into $\mathrm{m} 1, \mathrm{~m} 2, \mathrm{~m} 3, \mathrm{~m} 4$ and $\mathrm{m} 5$ subtypes (39). Pharmacologically, $\mathrm{M}_{1}, \mathrm{M}_{2}, \mathrm{M}_{3}$ and $\mathrm{M}_{4}$ subtypes correlate with $\mathrm{m} 1, \mathrm{~m} 2, \mathrm{~m} 3$ and $\mathrm{m} 4$ gene products, respectively, although a pharmacological correlate of the $\mathrm{m} 5$ gene product has not been identified (39).

Data indicate that most smooth muscles, including human ileum (40) and colon (41), contract in response to muscarinic $M_{3}$ receptor activation, even though this receptor forms a small percentage of the total muscarinic receptor population in the tissues studied to date. Gomez et al (42) identified muscarinic $M_{2}$ and $M_{3}$ receptors in both rat and human colon, although the radioligand binding data suggest that the proportions differ between the two species, with $\mathrm{M}_{2}$ receptors being predominant in the human colon. The difference in the muscarinic $M_{2}$ to $M_{3}$ receptor proportions between human and rat may reflect genuine species variation or postmortem changes occurring in human tissue after removal. It is also possible that the proportion of muscarinic $\mathrm{M}_{2}$ to $\mathrm{M}_{3}$ receptors is modified by disease. Indeed, human HT-29 colon carcinoma cells express a homogeneous population of $M_{3}$ receptors, with no evidence of $M_{2}$ receptors (43). Nonetheless, under appropriate experimental conditions, the majority of muscarinic $\mathrm{M}_{2}$ receptors are functional, principally after depletion of muscarinic $\mathrm{M}_{3}$ receptors. In vitro experiments $(44,45)$ have shown that ileal contraction can be mediated indirectly by $\mathrm{M}_{2}$ receptors 


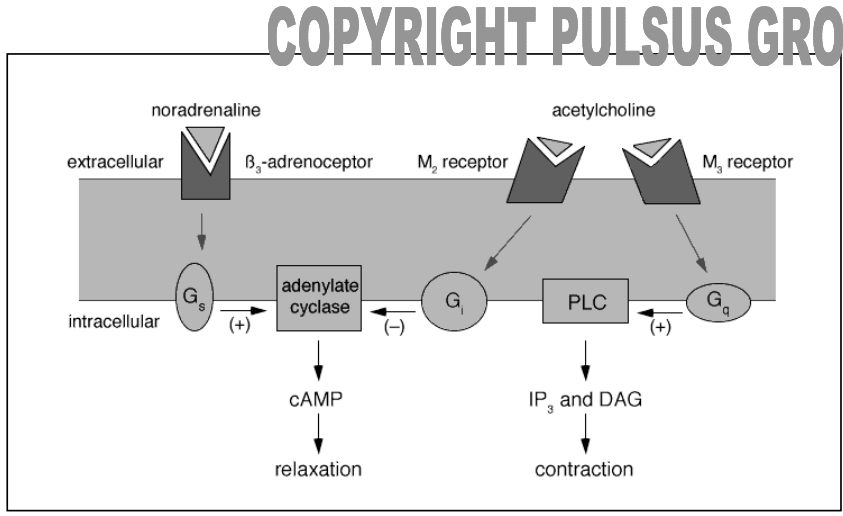

Figure 1) The balance between the relaxant and contractile state of the smooth muscle depends on the prevailing parasympathetic and sympathetic drive. In this model, both muscarinic $\mathrm{M}_{2}$ and $\mathrm{M}_{3}$ receptors modulate the contractile state of the tissue. $\mathrm{M}_{3}$ receptors mediate contraction by coupling to the $\mathrm{G}$ protein $\mathrm{G} q$, mobilizing inositol $(1,4,5)$-triphosphate $\left(\mathrm{IP}_{3}\right)$ and diacylglycerol (DAG) and, consequently, elevating intracellular calcium ion levels. Stimulation of beta ${ }_{3}$-adrenoceptors causes relaxation by enhancement of adenylate cyclase activity, while activation of $\mathrm{M}_{2}$ receptors, by coupling to $\mathrm{G} i$, inhibits this augmentation. Reproduced with permission from reference 46

(as a result of inhibition of relaxation caused by beta-adrenoceptor stimulation) and directly by $\mathrm{M}_{3}$ receptors. $\mathrm{M}_{2}$ receptors may mediate the dominant parasympathetic control over smooth muscle tone under conditions of highly sympathetic activity or where $\mathrm{M}_{3}$ receptors are dysfunctional. The parasympathetic control of smooth muscle contractility may thus occur directly, via the muscarinic $\mathrm{M}_{3}$ receptor activation, and indirectly, via $\mathrm{M}_{2}$ receptor stimulation (46). In this model (Figure 1), the muscarinic $\mathrm{M}_{2}$ receptor serves to op-
INC, DO NOT COPY

pose relaxant responses induced by elevation of intracellular cAMP. Consequently, the regulation of intracellular cAMP levels, as in the myocardium, is reciprocally regulated by the sympathetic and parasympathetic nervous systems. The physiological consequences of this model remain unknown, although one may speculate as to its function. Muscle relaxation may occur during the relaxant phase of peristalsis. This phase is presumably dominated by sympathetic drive to the muscle, while parasympathetic control is inhibited. Alternatively, when active contraction takes place (during peristalsis), both muscarinic $\mathrm{M}_{2}$ and $\mathrm{M}_{3}$ receptors are activated, and the sympathetic system is reciprocally inhibited (46).

An important therapeutic indication for muscarinic receptor antagonists is to relax smooth muscle, with the degree of relaxation produced depending upon the level of pre-existing cholinergic tone. In general, muscarinic $\mathrm{M}_{3}$ receptors appear to mediate contraction of most types of smooth muscle studied in detail to date. Selective blockade of muscarinic $\mathrm{M}_{3}$ receptors, therefore, should be therapeutically useful in the treatment of painful GI disorders, such as IBS $(47,48)$. The advantage of such compounds lies in the potential for reduced incidence of side effects, including blurred vision, increased heart rate, heat intolerance, sedation and mild confusion (49). These effects, uncomfortable in the young, may be serious in the elderly, because they are exacerbated with age (49).

Zamifenacin (UK-76,654) and darifenacin (UK-88,525) are two selective $M_{3}$ receptor antagonists that are under clinical evaluation for the treatment of IBS. Both compounds inhibit gut motility in the absence of cardiovascular effects and with a certain degree of selectivity over inhibi-

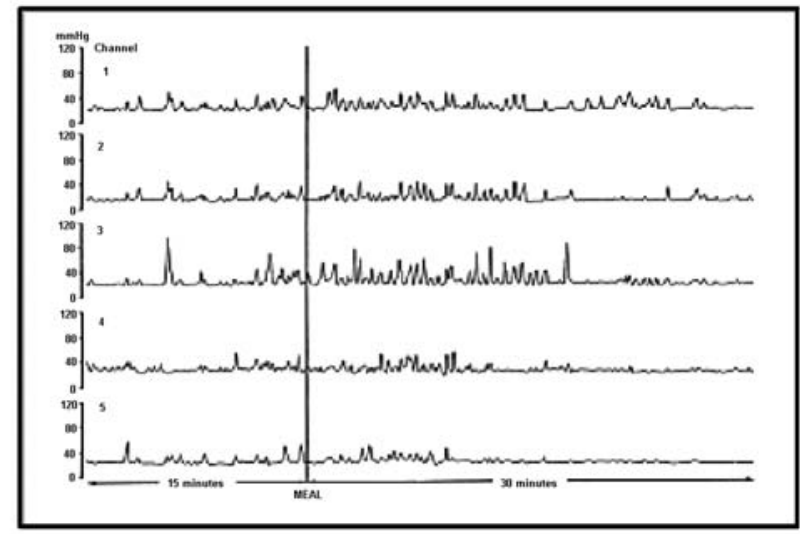

Placebo

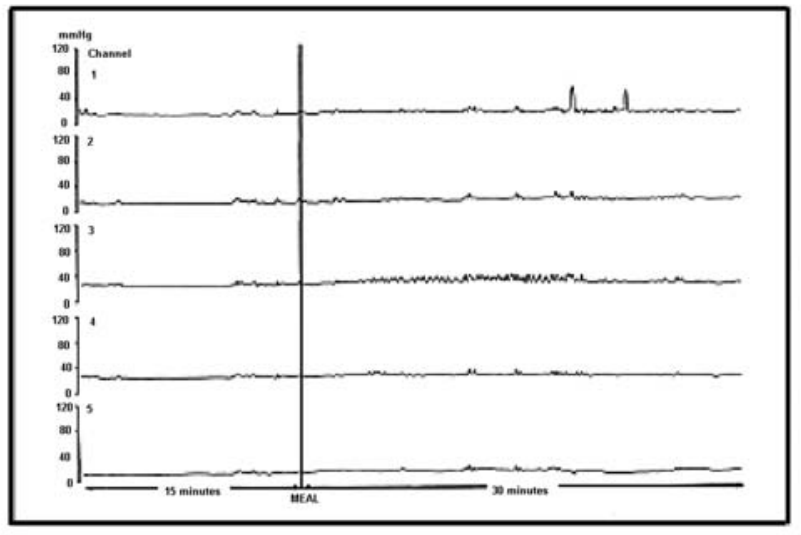

Zamifenacin (40 mg orally)

Figure 2) Inhibition of colonic motility by zamifenacin in a patient with irritable bowel syndrome. Left Fasting and postprandial colonic motility in basal conditions. Right Fasting and postprandial colonic motility after oral intake of zamifenacin $(40 \mathrm{mg})$. Channels 1 to 5 are motility recordings obtained from pressure transducers situated 35, 30, 25, 20 and $15 \mathrm{~cm}$ from the anal verge. Reproduced with permission from reference 50 
tion of salivary secretion $(47,48)$. In healthy volunteers, zamifenacin was able to inhibit small and large bowel motility and to accelerate gastric emptying over a dose range that was associated with minimal anticholinergic side effects (47). Resting and postprandial colonic motility were strongly reduced after a single oral dose $(40 \mathrm{mg})$ of zamifenacin (Figure 2) in IBS patients (50), suggesting that developing selective antimuscarinic agents may be a promising approach in the treatment of pain-predominant IBS. Although the molecular basis for zamifenacin and darifenacin selectivity is unknown, it seems unlikely that it arises from additional actions because radioligand studies have shown that the compounds do not bind to a wide range of receptors. Because multiple muscarinic receptors, including inhibitory $M_{1}$ receptors $(51,52)$, control gut function, it is possible that, through selective blockade of excitatory $\mathrm{M}_{3}$ receptors, these drugs reveal the inhibitory actions of Ach acting through $M_{1}$ receptors. Thus, the net functional effect of selective $\mathrm{M}_{3}$ antagonists on gut function may be achieved via blockade of $M_{3}$ receptors and by agonist-induced inhibition via $M_{1}$ receptors.

If one assumes that the model outlined in Figure 1 is physiologically appropriate, responses of smooth muscle to parasympathetic activation should be considered equally in terms of opposing relaxation and augmenting contraction. Participation of both muscarinic $\mathrm{M}_{2}$ and $\mathrm{M}_{3}$ receptors in the maintenance of muscle tone implies that current development of selective muscarinic $\mathrm{M}_{3}$ receptor antagonists is at least arguable. Indeed, studies in isolated tissue, admittedly of animal origin, show that reducing muscarinic $\mathrm{M}_{3}$ receptor function predisposes the tissue to contraction via the muscarinic $\mathrm{M}_{2}$ receptor. It is unknown whether the ratio of muscarinic $M_{2}$ to $M_{3}$ receptors changes in diseases such as IBS. Interestingly, in a model of airway hypersensitivity, the muscarinic $\mathrm{M}_{2}$ receptor may assume a greater importance because in atopic, sensitized rabbit trachea, muscarinic $\mathrm{M}_{2}$ receptor density and coupling are enhanced (53). The paucity of information in this area clearly reflects the lack of data reported using human tissue from normal and diseased states. Beta $_{3}$-adrenoceptor agonists: Since Bayliss and Starling's (54) early studies demonstrating inhibition of intestinal motility after splanchnic nerve stimulation, a large body of literature (reviewed in 55 and 56) has accumulated suggesting the involvement of adrenergic pathways in the physiological control of intestinal motility and secretion. While alpha ${ }_{1}$-adrenoceptors are located postsynaptically on smooth muscle cells and, to a lesser extent, on intrinsic neurons, alpha2-adrenoceptors are present both pre- and postsynaptically, with presynaptic auto- and heteroreceptors playing an important role in the modulation of neurotransmitter release. Postjunctional beta-adrenoceptors (initially charac-

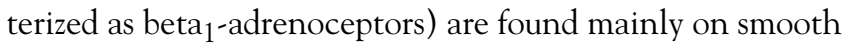
muscle cells, where they mediate muscle relaxation.

Early studies using a variety of synthetic beta- adrenoceptor antagonists suggested the existence of atypical beta-adrenoceptor-mediated responses that were clearly distinct from the traditional effects mediated by the beta ${ }_{1}$ - and

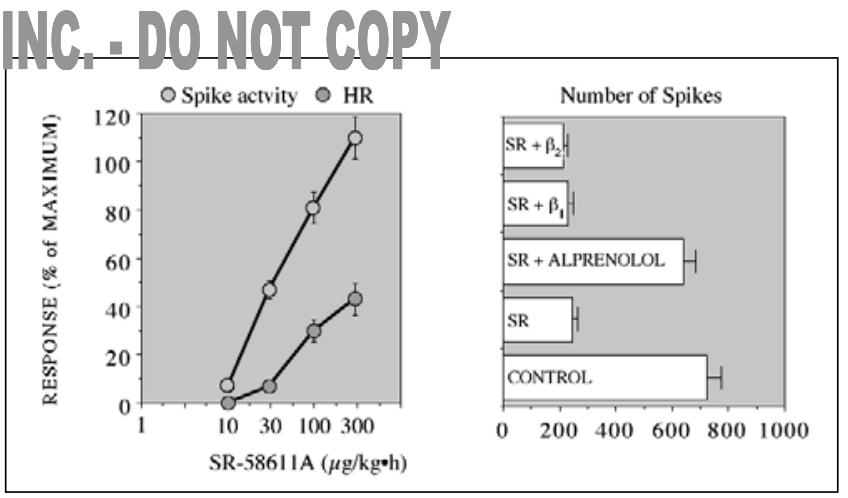

Figure 3) Inhibitory effect of SR-58611A (SR) on canine colonic motility. Left Dose-response relationships for inhibition of spike activity in the first phase of the gastrocolic response and induction of tachycardia. Responses (means \pm SEM) are expressed as percentages with respect to the response to a supramaximal dose of atropine. Note the dissociation between the colonic inhibitory effect and the positive chronotropic effect. Right Effect of beta-adrenoceptor antagonists (each at a dose of $300 \mu \mathrm{g} / \mathrm{kg}$ intravenous bolus followed by $300 \mu \mathrm{g} / \mathrm{kg} \cdot \mathrm{h}$ ) on the response to $100 \mu \mathrm{g} / \mathrm{kg}$ SR-58611A. CGP-20712A was used as a beta 1 -antagonist

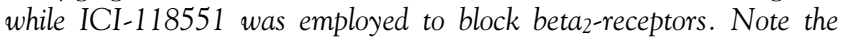
inhibition of gastrocolic response (expressed as number of spikes in the $10 \mathrm{~min}$ period after the meal) by SR-58611 A and the antagonism by alprenolol but not by selective beta 1 - or beta2-adrenoceptor blockade. HR Heart rate. Reproduced with permission from reference 64

beta2-adrenoceptors. This atypical beta-adrenoceptor, which was initially proposed to exist in the adipose tissues and later in the digestive tract of rodents, was referred to as betaz-adrenoceptor. Acceptance of the functionally based concept of a betaz-adrenoceptor was boosted on structural grounds by molecular biology studies. Sequence analysis indicated the existence in humans and rodents of genes coding for a third subtype of beta-receptor that, when expressed in transfected heterologous cells, had a pharmacological profile distinct from the previously established subtypes (57). Finally, aryloxypropanolaminotetralins have been synthesized as the first selective antagonists of beta 3 -adrenoceptors, thus providing unambiguous conclusive evidence of their distinctive functional features. Several in vitro and in vivo studies have now confirmed the presence of inhibitory beta 3 -adrenoceptors in small and large bowel of different animal species $(56,58)$, including humans (59). Expression of these receptors in human tissues is well documented because the mRNA of beta 3 -adrenoceptors has been detected in adipose tissues and GI tract (stomach, small intestine, colon and gallbladder) of adults $(60,61)$ and children $(60)$.

The therapeutic potential in gastroenterology of the newer compounds that target the betaz-adrenoceptor is suggested by their potent intestinal action in vivo in animal models, without any of the cardiovascular (Figure 3 ) or other unwanted effects of conventional beta-adrenoceptor agonists and antagonists, and by the clinically confirmed importance of beta-adrenergic control of motor function throughout the alimentary canal (55). Theoretically, the use of a beta-adrenoceptor agonist as an antispasmodic drug might even have an advantage over the use of antimuscarinic agents because the former compounds directly relax 


\section{COPYRIGHT PULSUS GROUP INC, : DO NOT COPY}

smooth muscle, while the latter can only counteract an excessive cholinergic tone. Although several beta 3 -agonists have been synthesized (62), only phenylethanolaminotetralines proved to be gut-selective (63). Among these derivatives, SR-58611A (64) is available for human studies, and phase II clinical trials are ongoing. Delvaux et al (65) observed an increase in rectal sensory thresholds, without a significant modification of the rectal compliance, after oral administration of the drug $(40 \mathrm{mg})$ to healthy volunteers. SR-58611A was well tolerated, and no effect on heart rate was detected (65).

However, despite the attractive theoretical advantages of beta 3 -agonists, an open question concerns the incidence of species-related differences in beta 3 -adrenoceptors (58), and, as a consequence, the effectiveness of these compounds as antispasmodics in human beings.

$\mathrm{NK}_{2}$ receptor antagonists: The tachykinins (TKs) are a family of small peptides whose common structural feature is the C-terminal aminoacid sequence phenylalanineX-glycineleucine-methionine- $\mathrm{NH}_{2}$, where $\mathrm{X}$ is an aromatic (phenylalanine or tyrosine) or hydrophobic (valine or isoleucine) residue. Three peptides of this family, substance $P, N K A$ and $\mathrm{NKB}$, have an established role as neurotransmitters in mammals (66).

The use of selective agonists in both functional and binding studies has provided unequivocal evidence for the existence of three types of $\mathrm{TK}$ receptors: $\mathrm{NK}_{1}$ (substance P-preferring), $\mathrm{NK}_{2}$ (NKA-preferring) and $\mathrm{NK}_{3}$ (NKB-preferring); there is also preliminary evidence for the existence of further subtypes. These results have been confirmed by the development of selective antagonists, and by the identification and cloning of three distinct cDNA sequences $(67,68)$. All three receptors belong to the superfamily of $G$ protein-coupled receptors and are linked to the phosphoinositide transmembrane-signalling pathway (67).

TKs enhance motor activity in virtually all regions and layers of the mammalian gut (69). In many instances, this action depends not only on a direct activation of the muscle, but also on stimulation of enteric motor neurons that excite the muscle by release of $\mathrm{ACh}$ (66). Despite large species differences, the distribution of motility controlling TK receptors is such that, typically, $\mathrm{NK}_{2}$ receptors are located on smooth muscle cells and $\mathrm{NK}_{3}$ receptors on enteric neurons, while $\mathrm{NK}_{1}$ receptors reside on both muscle and nerve (69). Besides their prominent excitatory action, TKs also exert inhibitory influences on motor activity by either stimulating inhibitory neural pathways or interrupting excitatory relays (69). There is abundant evidence that endogenous substance $\mathrm{P}$ and NKA participate in the neural stimulation of motility in synergism with $\mathrm{ACh}$, with which they are coreleased from enteric neurons (66). This synergistic action, which seems to be particularly relevant for the enteric control of peristaltic motor activity, needs to be borne in mind when the implications of TKs in GI motor regulation are analyzed and considered as a potential target for therapeutic intervention.

Functional studies with isolated gut segments and auto- radiographic receptor mapping indicate that both $\mathrm{NK}_{1}$ and $\mathrm{NK}_{2}$ receptors are expressed in human small intestine. Binding sites for substance P occur on the longitudinal muscle, myenteric plexus, circular muscle and muscularis mucosae, while binding sites for NKA are present on the muscle but absent from the plexus (70). The longitudinal muscle of the ileum is contracted by $\mathrm{NKA}$, substance $\mathrm{P}$ and $\mathrm{NK}_{2}$ receptor-selective agonists, whereas $\mathrm{NK}_{1}$ agonists are virtually inactive (71). This observation and the much higher potency of NKA compared with that of substance P show that $\mathrm{NK}_{2}$ receptors exclusively determine the excitatory action of TKs on the longitudinal muscle. The situation in the circular muscle is not much different, although the existence of functional receptors has been demonstrated (72). These motor responses apparently are brought about by a direct action on the muscle because they are not affected by atropine. $\mathrm{NK}_{3}$ receptors seem to be absent from the human small intestine because $\mathrm{NK}_{3}$ agonists fail to stimulate motor activity (72), and specific binding sites for NKB are not demonstrable (70). The longitudinal and circular muscle layers of the human isolated colon are very sensitive to $\mathrm{NKA}$ and $\mathrm{NK}_{2}$ agonists, while substance $\mathrm{P}, \mathrm{NK}_{1}$ and $\mathrm{NK}_{3}$ agonists are comparatively weak in causing a contraction (73-75). It appears, therefore, that TKs contract the human colon too predominantly via stimulation of $\mathrm{NK}_{2}$ receptors. However, the muscle layers of the human colon exhibit specific binding for substance P, which is though to reflect $\mathrm{NK}_{1}$ receptors $(70,76)$. Additional binding sites occur in the enteric nervous plexuses of the human colon (70), which may explain why the motor-stimulating responses to TKs are partially inhibited by tetradotoxin, atropine and hexamethonium (74).

Despite the wealth of information regarding the actions of TKs on gut motility there is relatively little information as to possible alterations of the TK system in GI disease. Evidence, however, is accumulating to suggest that some of the motor changes associated with intestinal anaphylaxis, infection, inflammation and stress are related to functional alterations of intrinsic enteric or extrinsic primary afferent neurons releasing TKs (77). The inference that TKs are involved in a number of motor disturbances raises the possibility that TK receptor-selective antagonists could therapeutically be exploited for the correction of disordered gut motility.

The available TK antagonists can be roughly grouped into two main categories - peptidic (obtained from modification of TK amino acid sequence) and nonpeptidic (reviewed in 78). Selective antagonists to each type of TK receptor have been discovered, but, because $\mathrm{NK}_{2}$ receptor activation in animal and human bowel increases motility and may give rise to muscle spasm, $\mathrm{NK}_{2}$ antagonists are being developed as antispasmodic compounds. Indeed, $\mathrm{NK}_{2}$ antagonists are spasmolytic in the rat small intestine in as much as they prevent the increase in small intestinal transit caused by an $\mathrm{NK}_{2}$ agonist (79) but lack any constipating activity (80). Among the selective $\mathrm{NK}_{2}$ antagonists, three compounds are available for human studies. SR-48,968 (81), a nonpeptide derivative, is already in phase II clinical trials, 
COPYRIGHT PULSUS GROUP

while clinical investigation is being planned for the polycyclic exapeptide derivatives MEN-10627 and MEN-11420 (82).

Gut-selective calcium channel blockers: Several calcium channel blockers used for the treatment of cardiovascular disorders have recently been tested for their effects on GI motility. The rationale for this approach centres on the concept that calcium channel blockers are at least as potent in inhibiting intestinal smooth muscle as in relaxing vascular smooth muscle (83).

Calcium channels can be viewed as macromolecular pores allowing the passage of calcium ions from the extracellular space into cells (Figure 4) and can be divided into two major categories - voltage-operated channels (VOCs) and receptor-operated channels (ROCs). Activation of VOCs is due to changes in membrane potential, while ROCs are voltage insensitive and respond to membrane-mediated alterations other than a change in potential (84). Studies from smooth muscle cells isolated from guinea pig (Taenia coli) (85) have shown that - as with cardiac and vascular smooth muscle cells - VOCs can be subdivided into L-type (long lasting) and T-type (transient) on the basis of the characteristics of the calcium ion current within the channel. $\mathrm{N}$-type (neuronal) VOCs with intermediate characteristics have been detected in enteric neurons (86).

Calcium channel blockers are a heterogeneous group of agents that differ from chemical, pharmacological and therapeutic points of view. Because more than 70 different drugs are claimed to act as calcium antagonists, an ad hoc committee tried to establish a classification based on the site of action (87); however, this classification failed to include some special agents. A fully satisfactory subdivision is attained by considering the cellular mechanism of action of these compounds. The so-called calcium entry blockers or slow channel blockers prevent the slow influx of extracellular calcium through specific channels in the membrane. In contrast, calmodulin-antagonists such as trifluoroperazine and structurally related antipsychotic drugs decrease the cellular effects of calcium without lowering the intracellular calcium concentration. They block the calcium-dependent processes by interfering with the regulatory protein calmodulin, which subserves most of the calcium-dependent functions. The calcium-blocking agents (namely verapamil, nifedipine and diltiazem), which are available and widely used for the treatment of cardiovascular diseases, all inhibit the entry of calcium into cells and may affect smooth muscle tone of many organs throughout the body, including the GI tract.

The mechanisms by which calcium channel blockers inhibit GI motility include a direct action on the smooth muscle by inhibiting the calcium entrance into the cells through blockade of VOCs (83), modulation of transmitter release from nerve terminals (88) and stimulation of water absorption (89), with consequent decrease of lower GI motility.

There are more detailed studies on the effects of calcium channel blockers in the esophagus than on their effects on other parts of the GI tract (90). This is because the esophagus lends itself more easily to evaluation. On the contrary,

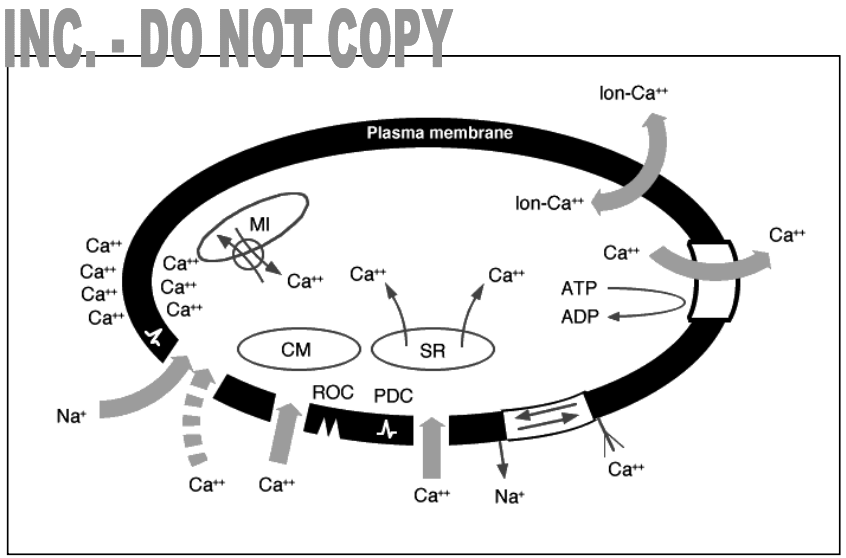

Figure 4) Calcium homeostasis in the smooth muscle. Calcium influx can occur through the potential-dependent calcium channels (PDCs) or voltage-dependent calcium channels, and receptor-operated calcium channels (ROCs). Additionally, calcium influx can occur as one component of a plasmalemmal sodium-calcium exchange process that can operate in either direction. Calcium pumping is represented by a plasmalemmal calcium-ATPase, but calcium sequestration (and release) can take place at several intracellular sites, including calmodulin (CM), mitochondria (MI), sarcoplasmic reticulum (SR) and the internal surface of the plasma membrane

there is only fragmentary information concerning the effects of these drugs on small and large bowel motility in humans (reviewed in 91). On the whole, after administration of calcium channel blockers, postprandial motility was found to be reduced and orocecal and colonic transit delayed (91). Both nifedipine (20 mg sublingually) and nicardipine (10 mg intravenously) reduced the colonic motor response to a standard meal in IBS patients $(92,93)$. Nifedipine (20 or $40 \mathrm{mg}$ orally) can also inhibit the abnormal motor response to distension in IBS patients (94). Finally, an increase in rectal sensory threshold was detected after nicardipine $(20 \mathrm{mg})$ in patients but not in healthy subjects (95).

Different methods could be attempted to minimize the cardiovascular side effects of calcium channel blockers, thus allowing their potential to be exploited in patients with IBS. One method is the development of pharmaceutical preparations delivering the drug to the colon, eg, a pH-dependent release preparation, and another the design of new agents having only a local action on the gut. While no site-specific preparations of calcium channel blockers are available, some gut-selective drugs have been developed and are being used as antispasmodics in IBS. Among these, pinaverium bromide is the most widely known. Evidence indicates that this drug relaxes GI smooth muscle mainly through specific inhibition of calcium ion influx through VOCs that exist on the surface membranes of smooth muscle cells (96). Its in vivo selectivity for the GI tract appears to be due mainly to its pharmacokinetic properties. Because of its low absorption, typical for quaternary ammonium compounds, and its efficient hepatobiliary excretion, most of the orally administered dose of pinaverium bromide remains within the GI tract (97). Not only systemic (98) but also local (99) administration of the drug was found to be effective in reducing meal- or neostigmine-induced colonic motility. Interestingly enough, while two small clinical trials with diltiazem 


\section{COPYRIGHT PULSUS GROUP INC, D DO NOT COPY}

and verapamil in IBS (reviewed in 100) had disappointing results, pinaverium bromide ( $50 \mathrm{mg}$ tid) was better than placebo in improving abdominal pain and constipation, an effect most likely due to the observed acceleration of colonic transit time (101).

Octylonium bromide is another smooth muscle relaxant found by a recent meta-analysis (18) to be effective in the treatment of IBS symptom complex. Besides being an antimuscarinic, the drug interferes with calcium ion mobilization, blocking both the cation entry and its release from intracellular stores (102). Recent experiments (103) on isolated rat chromaffin cells suggest that octylonium bromide binds to VOCs. Because of its poor GI absorption (104), which underlines the lack of untoward effects, octylonium bromide is largely available at the intraluminal level. Autoradiographic studies have shown that, after oral administration, the drug accumulates in the colonic and rectal smooth muscle (105).

\section{Motor-stimulating drugs}

Although GI motility is currently stimulated with dopamine antagonists, or direct or indirect cholinergic drugs, recent evidence strongly suggests that blockade of cholecystokinin $(\mathrm{CCK})_{\mathrm{A}}$ receptors and stimulation of motilin receptors are also promising avenues. Because drugs acting on 5-HT receptors, such as cisapride, are the best available motorstimulating compounds, new derivatives are being developed as gastrokinetic drugs.

CCK receptor antagonists: It is well known that minute amounts of CCK are able to affect GI motility under all possible in vivo and in vitro experimental conditions in both animals and humans (106), suggesting this action on the gut to be one of the physiological actions of the peptide. In the small and large intestine, CCK has a mixture of stimulatory and inhibitory effects on motility, although the stimulatory effects are largely predominant. In the first part of the duodenum, the peptide has an inhibitory effect on the motility index and basic electric rhythm frequency, which resembles its relaxant effect on the sphincter of Oddi. In the small bowel CCK induces a postprandial-like motility pattern, while in the colon it stimulates electrical spike activity associated with segmenting contractions (107). In line with this concept, recent data suggest that CCK exerts an inhibitory effect on the propulsive motility in the ascending colon (108). Physiological doses of CCK, however, fail to modify phasic contractility, tone or transit in healthy subjects $(109,110)$, suggesting that endogenous CCK does not play a major physiological role in the regulation of interdigestive and postprandial colonic motility.

It is well established that CCK exerts its physiological effects by binding with specific receptors located on target cells. At least two different receptors mediate CCK biological actions $-\mathrm{CCK}_{\mathrm{A}}$ and $\mathrm{CCK}_{\mathrm{B}}$ receptors $(111,112)$. The $\mathrm{CCK}_{\mathrm{A}}$ receptor mediates most of the activities of $\mathrm{CCK}$ in the GI system. It is present on the pancreatic acinar cells and gallbladder as well as in the alimentary tract muscle, neurons in the myenteric plexus, vagal afferents from the GI tract and certain brain nuclei. The $\mathrm{CCK}_{\mathrm{B}}$ receptor is mainly a brain receptor and probably modulates the actions of $\mathrm{CCK}$ in the central nervous system. Extensive evidence indicates that $\mathrm{CCK}_{\mathrm{A}}$ receptors are also present in the brain and $\mathrm{CCK}_{\mathrm{B}}$ receptors in the periphery (113); however, the original nomenclature still holds. A third receptor was initially believed to be a third subtype of the CCK receptor and was named the 'gastrin' receptor because it was characterized on isolated canine parietal cells; this receptor has subsequently been shown to be identical to the $\mathrm{CCK}_{\mathrm{B}}$ receptor (113) and, therefore, is also referred to as the $\mathrm{CCK}_{\mathrm{B}}$ / gastrin receptor.

Ten classes of CCK antagonists including hundreds of compounds have been described (114). These antagonists have been used successfully in animals to confirm the classical actions of CCK as well as to explore novel activities, including its role as a neuropeptide (111). At present, of the six $\mathrm{CCK}_{\mathrm{A}}$ receptor antagonists tested in humans, only three are still under development for potential clinical applications the two proglumide derivatives loxiglumide and its active enantiomer dexloxiglumide (currently in phase III) and the indolyl derivative SR-27897B (currently in phase II). The substitute benzodiazepine derivatives devazepide and FK-480, and the aspartic acid derivative 2-NAP have been discontinued because they cause gallstone formation and acute renal failure, respectively. Only one abstract dealing with SR-27897B is available in the literature. Indeed, almost all the published clinical investigations have been performed with loxiglumide.

The effects of loxiglumide on small bowel transit time and colonic transit time have been studied in healthy volunteers by means of the hydrogen breath test and radiopaque markers, respectively (115). In experiments evaluating intestinal transit, the CCK antagonist was infused intravenously $(10 \mathrm{mg} / \mathrm{kg} \cdot \mathrm{h})$ starting $60 \mathrm{mins}$ before intraduodenal administration of the test meal, whereas, in experiments evaluating colonic transit, the compound $(800 \mathrm{mg}$ ) was given three times daily for seven days. Compared with placebo, loxiglumide did not significantly affect small bowel transit, whereas colonic transit was significantly accelerated. In line with these findings, dexloxiglumide was capable of accelerating colonic transit in an experimental model of constipation in humans $(116,117)$.

On the basis of the above results, a double-blind, randomized, placebo controlled, crossover study investigated the efficacy of loxiglumide in geriatric patients with chronic constipation (118). After a baseline phase, a three-week period of treatment with either loxiglumide ( $800 \mathrm{mg}$ tid) or placebo was started, followed by a one-week washout period and another three weeks of treatment with either placebo or loxiglumide. Compared with placebo, loxiglumide significantly accelerated colonic transit time and significantly increased the number of bowel movements (Figure 5) (118). Loxiglumide also decreased the need for enemas and did not modify $N$-benzoyl-tyrosyl-p-aminobenzoic acid test, thus showing that improvement of constipation was not due to drug-induced pancreatic insufficiency.

Because CCK is thought to be implicated in the genesis of 
COPYRIGHT PULSUS GROUP

gastrocolic response (119), the effect of $\mathrm{CCK}_{\mathrm{A}}$ antagonism on colonic motor response to intragastric fat was studied in healthy humans (120). Basal motility index (MI) in the sigmoid colon was higher during loxiglumide infusion $(10 \mathrm{mg} / \mathrm{kg} \cdot \mathrm{h})$ than during placebo administration. Intragastric administration of soya oil caused a significant increase of MI above baseline during placebo infusion but did not change the already elevated MI during loxiglumide administration. These data confirm that endogenous CCK acts as a mediator of gastrocolic response and demonstrate that the peptide has an inhibitory action on basal colonic motility, thus explaining the favourable effects of CCK antagonism in chronic constipation.

Another possible therapeutic application of $\mathrm{CCK}_{\mathrm{A}}$ antagonists, in addition to the treatment of constipation, is the treatment of IBS, where altered intestinal motility and heightened visceral perception coexist (121). Exogenous administration of CCK at doses in the physiological range demonstrated that ileal motility in response to this stimulation was greater in patients with IBS than in healthy controls (122). The first suggestion that CCK may be involved in the pathophysiology of IBS came, however, from earlier studies that showed that CCK administration to IBS patients exacerbates the symptoms of the disease (123). In addition to symptoms, particularly abdominal pain, CCK can also produce some of the motility disorders that are peculiar to the disease (124). These findings were further confirmed by a recent study (125) showing an exaggerated and prolonged CCK release in response to a fat meal in patients with IBS.

Results of a pilot therapeutic study using loxiglumide in IBS seem to indicate a therapeutic potential of $\mathrm{CCK}_{\mathrm{A}}$ antagonists in IBS and, therefore, confirm an involvement of CCK in the pathophysiology of IBS (126). The mechanism by which loxiglumide might be clinically beneficial is under investigation. Despite evidence indicating that a $\mathrm{CCK}_{\mathrm{A}^{-}}$mediated mechanism does not play a major role in the regulation of the interdigestive and postprandial motility of the left colon (109), loxiglumide at clinical doses interferes with the gastrocolic reflex and ileal motility, and is able to selectively slow proximal colonic transit time in IBS patients (127). In addition, at the same clinical doses, loxiglumide significantly decreases the postprandial increase of rectal sensations and pain in IBS patients. Interestingly enough, these changes were not paralleled by relevant motility changes (personal communication).

Motilin receptor agonists: Motilin seems to affect mainly, but not exclusively, the proximal part of the GI tract (128). The peptide has no significant influence on gut contractile activity during the digestive state. Conversely, in the interdigestive state it induces the cyclic recurrent episodes of caudal moving bands of strong contractions that move from the lower esophageal sphincter to the terminal ileum. Little attention has been paid to a possible role for motilin in the regulation of motility of the large intestine. It was reported that the peptide increases colonic myoelectric activity and pressures as well as initiates a premature giant migrating mo-

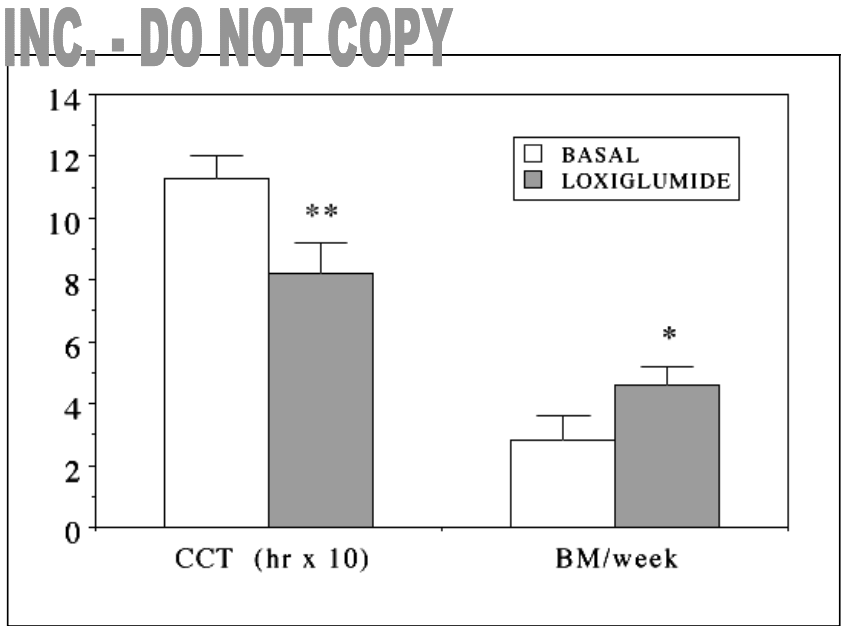

Figure 5) Effect of a three-week treatment with loxiglumide (800 mg tid) on colonic transit time (CCT) and bowel movements (BM)/week in geriatric patients with chronic constipation. $* P<0.05$; $* * P<0.01$. Data from reference 118

tor complex in the cecum of the dog (128). These effects have, however, been considered pharmacological rather than physiological. The recent discovery of motilin receptors in colonic smooth muscle (129), with a density higher than that found in the antrum and duodenum, shed new light on the physiological role of motilin and opened new perspectives for the therapeutic applications of drugs acting on motilin receptors.

Motilin binding sites have been found on the smooth muscle layers of the gastric antrum, duodenum and colon, but no positive binding reaction has been detected in the cecum. Specific binding sites are particularly abundant in the circular muscle layers, with low concentrations in the longitudinal muscle layers of the gastric antrum, duodenum and colon (130). Specific motilin receptors have been identified on the GI muscle (including the colonic one) of several animal species $(111,131)$.

More than 10 years ago it was shown for the first time that erythromycin mimics the effect of motilin on GI motility (132). Erythromycin and related 14-member macrolide compounds inhibit the binding of motilin to its receptors on GI smooth muscle membranes and may, therefore, act as motilin agonists $(133,134)$. The contractile activity of these drugs is similar to that induced by motilin and cannot be blocked by atropine or tetrodotoxin, thus suggesting a direct effect on smooth muscle cells (134). In isolated colonic smooth muscle (129), erythromycin displaced ${ }^{125}$ iodinelabelled motilin, suggesting that the two substances bind to the same receptors. In the rabbit, this macrolide antibiotic simulates mechanical and electrical activity of the colon in a dose-dependent manner, with a mechanism dependent on the influx of extracellular calcium (135).

While the gastric motor effect of erythromycin in both healthy subjects and patients with gastroparesis is well established $(111,131)$, conflicting data have been reported for small and large bowel motility. Indeed, Bradette et al (136) found that, while in the interdigestive period erythromycin induces a postprandial motility pattern in the sigmoid re- 


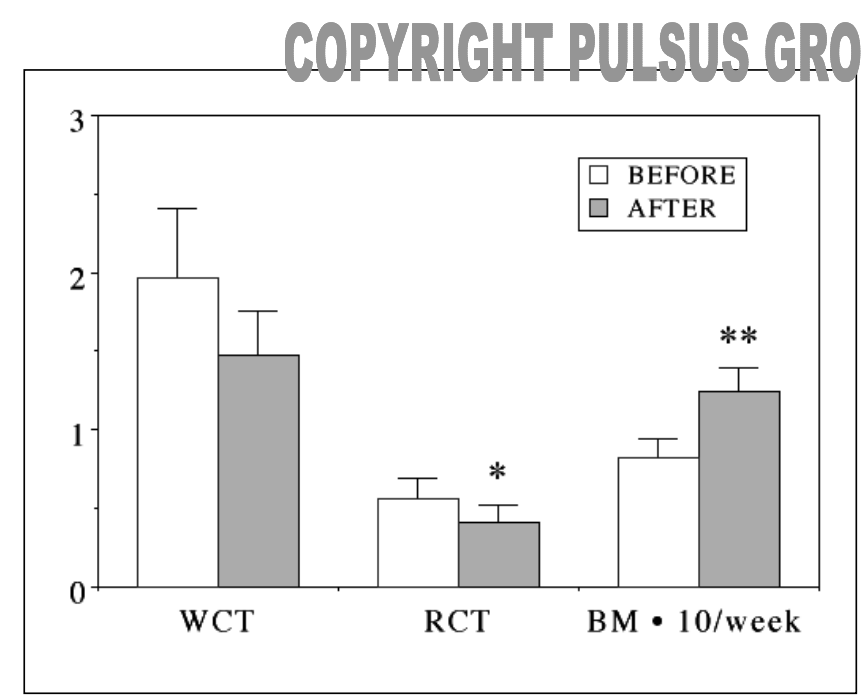

Figure 6) Effect of oral erythromycin ( $250 \mathrm{mg}$ qid) on colonic transit time and bowel movements (BM)/week in healthy volunteers. $* P<0.05$; **P<0.01. RCT Right colonic transit; WCT Whole colonic transit Data from reference 146

gion, it fails to modify postprandial contractile profiles. Jameson et al (137) were unable to find any affect on sigmoid manometric pattern. However, in chronically constipated subjects given intravenous erythromycin (500 $\mathrm{mg} \cdot \mathrm{h}$ ) Bassotti et al (138) found a significant increase in segmental contractile activity in the sigmoid, but not in the transverse and descending colon. Similarly, although some investigations $(139,140)$ found an acceleration of intestinal and/or colonic transit time after erythromycin administration in healthy volunteers, others $(137,141,142)$ were unable to confirm this finding. In any case, an acceleration of both transit times has been observed in patients (with chronic constipation, intestinal pseudo-obstruction or diabetes) in whom it was delayed (143-145). Both Hasler et al (146) and Sharma et al (147) found a significant decrease in transit time of the right colon, suggesting a shift in fecal distribution (Figure 6). Taken together, these data suggest that this macrolide antibiotic may be helpful in the treatment of constipation.

While screening a number of erythromycin derivatives, Omura et al (148) discovered a group of compounds with a loss in antibiotic potency but an increased potency to induce contractions and to mimic motilin. For this reason Itoh and Omura (149) proposed to give the name 'motilides' to all macrolides with a direct contractile effect in vitro on rabbit duodenal segments and the capacity to induce in vivo phase III activity in dogs. Peeters (131) proposed to use the name 'motilinomimetics' for any compound able to interact with the motilin receptor because the discovery of the prokinetic properties has also stimulated a renewed interest in motilin. Motilinomimetics may, therefore, in the future consist of two classes of compounds - motilides (macrolide derivatives) and motilin analogues. Several derivatives, devoid of antibacterial activity but endowed with affinity for motilin receptors, have been synthesized and are under preclinical and clinical (KW-5139, KC-11458EM-574 and
INC, DO NOT COPY

5-Hydroxytryptamine (5-HT) receptor ligands under clinical development

\begin{tabular}{|c|c|c|c|c|}
\hline \multirow[b]{2}{*}{ Drug } & \multirow[b]{2}{*}{ Company } & \multirow[b]{2}{*}{ Status } & \multicolumn{2}{|c|}{ Receptor activity } \\
\hline & & & $5-\mathrm{HT}_{4}$ & $5-\mathrm{HT}_{5}$ \\
\hline Mosapride & $\begin{array}{c}\text { Dainippon Pharma, } \\
\text { Osaka, Japan }\end{array}$ & Phase I/II & Agonist & - \\
\hline Fabesetron & $\begin{array}{c}\text { Fujisawa } \\
\text { Pharmaceutical Co, } \\
\text { Osaka, Japan }\end{array}$ & Phase II & Antagonist & Antagonist \\
\hline SB-207266 & SKB, Pennsylvania & Phase I/II & Antagonist & - \\
\hline Lintopride & $\begin{array}{c}\text { Synthelabo, Cedex, } \\
\text { France }\end{array}$ & Phase II & Agonist & Antagonist \\
\hline Zacopride & Synthelabo & Phase III & Agonist & Antagonist \\
\hline Prucalopride & $\begin{array}{l}\text { Novartis Pharma, } \\
\text { Basel, Switzerland }\end{array}$ & Phase III & $\begin{array}{l}\text { Partial } \\
\text { agonist }\end{array}$ & Antagonist \\
\hline Tegaserod & $\begin{array}{c}\text { Janssen-Cilag, } \\
\text { Bercham, Belgium }\end{array}$ & Phase II & $\begin{array}{l}\text { Partial } \\
\text { agonist }\end{array}$ & - \\
\hline
\end{tabular}

SKB SmithKline Beecham

ABT - 229) investigation (reviewed in 24). Further development will depend on the lack of antimicrobial activity and the absence of fading of the prokinetic effect during prolonged administration.

5- $\mathrm{HT}_{4}$ receptor agonists: Most of the 5-HT (serotonin) present in the adult human body is located in the GI tract. The vast majority is contained in enteroendocrine cells, and the rest exists mainly in myenteric interneurons separated from the mucosa by an intraenteric barrier. Physiological studies suggest that 5 -HT plays a vital role in mediating both sensory and reflex responses to GI stimuli; thus, this transmitter is closely implicated in gut reactions (150). Several studies have implicated 5-HT in the motor control of the gut (reviewed in 151), but how serotonin modulates this function in health and disease is not well understood. In bowel preparations, 5-HT indirectly causes smooth muscle contraction through Ach release from excitatory (cholinergic) neurons. 5-HT also directly activates smooth muscle, although this mechanism seems to be less important (152).

The use of selective agonists and antagonists has demonstrated that the biological actions of 5-HT are mediated by at least four types of receptors: $5-\mathrm{HT}_{1}$-like, $5-\mathrm{HT}_{2}, 5-\mathrm{HT}_{3}$ and the recently described $5-\mathrm{HT}_{4}$ receptor $(150,152)$. It is well known that metoclopramide is an effective, albeit weak, antagonist of $5-\mathrm{HT}_{3}$ receptors, which have been found only associated with peripheral autonomic, afferent and enteric neurons (153). The effectiveness of some selective $5-\mathrm{HT}_{3}$ antagonists as antiemetic and motor-stimulating compounds (such as ondansetron, granisetron and tropisetron), devoid of any effect at dopamine receptors, suggests that blockade of these sites plays an important role in the mechanism of action of metoclopramide (154). However, the lack of correlation between the potency of these compounds as $5-\mathrm{HT}_{3}$ receptor antagonists and their ability to stimulate GI motility is consistent with the idea that mechanisms other than blockade of $5-\mathrm{HT}_{3}$ receptors should be involved in their mo- 
COPYRIGHT PULSUS GROUP

tor stimulating activity (152). Rather, an agonistic activity at the level of $5-\mathrm{HT}_{4}$ receptors, located on nerve terminals of both cholinergic interneurons and motor neurons, and whose stimulation increases Ach release, seems to be the key mechanism of established (eg, cisapride) and new prokinetic compounds (reviewed in 155).

Although there are several relatively selective $5-\mathrm{HT}_{4}$ agonists in the substituted benzamide group (eg, renzapride, zacopride and clebropride), most of the available clinical trials have evaluated cisapride, whose stimulatory action on bowel motility has been discussed. As for its mode of action, it is at least difficult to associate the 'enterokinetic action' of cisapride with $5-\mathrm{HT}_{4}$ activation (156) because in the human isolated ascending and sigmoid colon, $5-\mathrm{HT}_{4}$ receptors inhibit the contractile activity of the circular muscle (157). Conversely, while cisapride does release Ach from the human stomach (158), the drug has proved to be incapable of releasing Ach from the human colon (159). 5- $\mathrm{HT}_{4}$ receptors, however, seem to be involved in the intestinal secretory activity of serotonin (160).

Although cisapride may be useful in some patients with constipation, it may actually be the prototype of 'enterokinetic compounds' for the management of delayed colorectal transit. Two such compounds, namely prucalopride (R-093877) and tegaserod (HTF-919), display a strong stimulatory action on the bowel, and are now in phase II and phase III clinical trials, respectively. R-093877 is a dihydrobenzofurancarboxamide, endowed with a potent, although partial, agonistic activity towards $5-\mathrm{HT}_{4}$ receptors (161). In a placebo controlled study of healthy volunteers, the drug was found to be capable of significantly increasing colonic transit time as well as the mean number of bowel movements per week (162). SDZ-HTF-919 is another partial 5-HT 4 agonist, belonging to the class of aminoguanidine-indole derivatives (163). A preliminary trial found an improvement in bowel function after short term drug administration in constipation-predominant IBS patients with delayed colonic transit (personal communication). This drug, as with other $5-\mathrm{HT}_{4}$ agonists under development (Table 1 ), is antagonistic towards $5-\mathrm{HT}_{3}$ receptors. The matter is rather puzzling because, in contrast, some $5-\mathrm{HT}_{3}$ antagonists display agonistic properties at the level of $5-\mathrm{HT}_{4}$ receptors and some are devoid of such an effect, while tropisetron (ICS 205-930) actually behaves (at high doses) as a $5-\mathrm{HT}_{4}$ antagonist (Figure 7) (152). Whatever the receptor subtype involved, novel drugs acting on 5-HT receptors are all capable of affecting upper and/or lower GI motility, and, provided that their action is confirmed in patients, new prokinetic compounds belonging to this class of drugs will be soon available for clinical use.

\section{OCTREOTIDE: MOTOR-INHIBITING DRUG OR PROKINETIC COMPOUND?}

Native somatostatin has variable effects on motor activity of the GI tract, depending on the physiological state and region studied. In the stomach, somatostatin inhibits the normal occurrence of cyclic interdigestive and fed motor activities

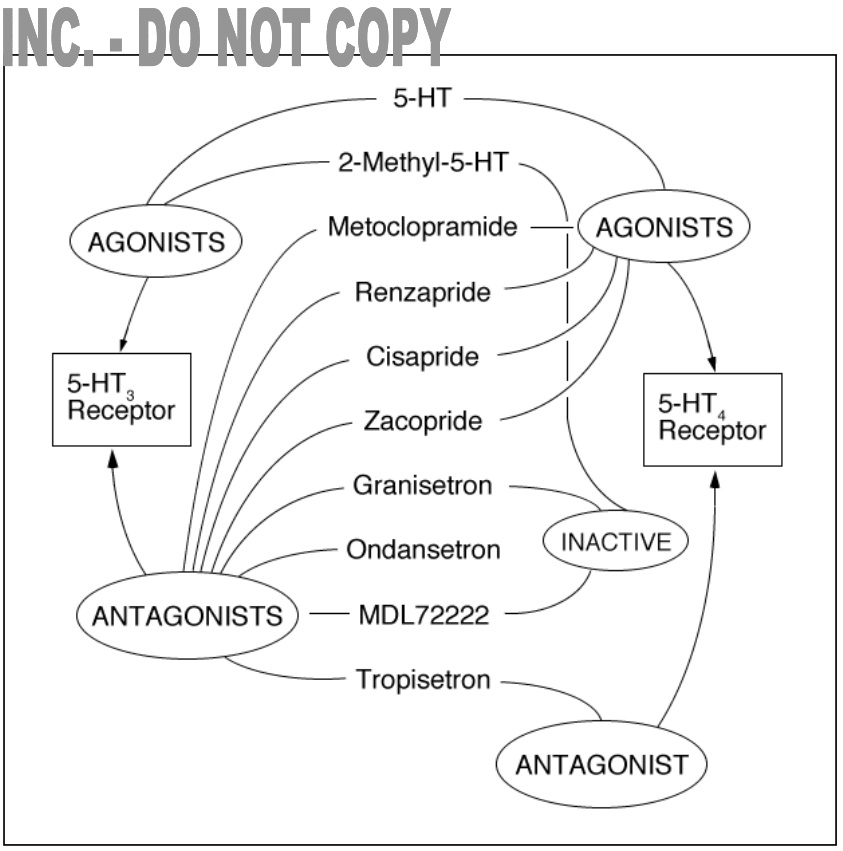

Figure 7) Activity of some drugs affecting gastrointestinal motility at 5-hydroxytryptamine $(5-\mathrm{HT})_{4}$ and $5-\mathrm{HT}_{3}$ receptor level. Reproduced with permission from reference 152

(164). In the intestine, the peptide initiates ectopic fronts under basal conditions but inhibits fed motility (165). When given $(50 \mu \mathrm{g} /$ day subcutaneously) to patients with scleroderma and intestinal pseudo-obstruction (166), the long acting somatostatin analogue octreotide (167) proved to be an effective prokinetic compound. Indeed, motility patterns in scleroderma patients were chaotic and nonpropagative but, after octreotide administration, became well coordinated, aborally directed and nearly as intense as those in healthy volunteers (166). A three-week treatment with the drug achieved a significant reduction in symptoms such as abdominal pain, bloating, nausea and vomiting. Additionally, there was an improvement in bacterial overgrowth, as objectively measured by the breath hydrogen test (166).

A thorough analysis of the effects of octreotide on GI pressure profiles (168) confirmed that it induces a small activity front followed by motor quiescence in both healthy subjects and patients with functional or organic GI disorders, and inhibited antral motility, suggesting that the drug is not effective in gastroparesis. A subsequent study (169) demonstrated that octreotide accelerates initial gastric emptying and inhibits small bowel transit, leaving the colonic transit unaltered. While these data support the use of the drug in diarrheal states, they do not provide a rationale for using octreotide to treat small bowel stasis syndromes. Therefore, the use of this synthetic peptide in GI motor disturbances needs to be evaluated further before any recommendation for clinical practice is given.

\section{CONCLUSIONS}

Drugs affecting small and large bowel motility are available, and several new ones are being developed. All the above compounds belong to a long line of drugs that have been 
touted as potential breakthroughs in the treatment of IBS. However, none of the other 'magic bullets' has withstood the objective scrutiny of controlled clinical trial testing, and it is difficult to imagine that these new agents will be any different. Further work is needed to determine the predictive value of objective abnormalities for the efficacy of a drug in the individual patient. This is the crucial point to define a rational strategy in clinical practice, especially to establish whether a functional investigation is needed before a motility modifying drug is given.

\section{REFERENCES}

1. Camilleri M, Neri M. Motility and stress. Dig Dis Sci 1989;34:1777-86.

2. Horowitz L, Farrar JT. Intraluminal small intestinal pressure in normal patients and in patients with functional gastrointestinal disorders. Gastroenterology 1962;42:455-64.

3. Kellow JE, Phillips SF. Altered small bowel motility in irritable bowel syndrome is correlated with symptoms. Gastroenterology 1987;92:1885-93

4. Gorard DA, Libby GW, Farthing MJ. Ambulatory small intestinal motility in "diarrhoea" predominant irritable bowel syndrome. Gut 1994;35:203-10.

5. Whitehead WE, Engel BT, Schuster MM. Irritable bowel syndrome. Physiological and psychological differences between diarrheapredominant and constipation-predominant patients. Dig Dis Sci 1980;25:404-13.

6. Bazzocchi G, Ellis J, Meyer J, et al. Colonic scintigraphy and manometry in constipation, diarrhea and inflammatory bowel disease. Gastroenterology 1988;94:A29. (Abst)

7. Bazzocchi G, Ellis J, Villaneuva-Meyer I, et al. Postprandial colonic transit and motor activity in chronic constipation. Gastroenterology 1990;98:686-93.

8. Cann PA, Read NW, Brown C, Hobson N, Holdsworth CD. Irritable bowel syndrome: relationship of disorders in the transit of a single solid meal to symptom patterns. Gut 1983;24:405-11.

9. Vassallo M, Camilleri M, Phillips SF, et al. Transit through the proximal colon influences stool weight in irritable bowel syndrome. Gastroenterology 1992;102:102-8.

10. Stivland T, Camilleri M, Vassallo M, et al. Scintigraphic measurement of regional gut transit in idiopathic constipation. Gastroenterology 1991;101:107-15.

11. Drossman DA, Whitehead WE, Camilleri M. Irritable bowel syndrome: a technical review for practice guideline development. Gastroenterology 1997;112:2120-37.

12. Müller-Lissner S, Coremans G, Dapoigny M, et al. Motility in irritable-bowel syndrome. Digestion 1997;58:196-202.

13. Klein KB. Controlled treatment trials in the irritable bowel syndrome: a critique. Gastroenterology 1988;95:232-41.

14. Cann P. Approach to the design of therapeutic trials in IBS. Scand J Gastroenterol 1987;22(Suppl 130):67-76.

15. Talley NJ, Nyren O, Drossman DA, et al. The irritable bowel syndrome: toward optimal design of controlled treatment trials. Gastroenterol Int 1994;6:189-211.

16. Camilleri M, Choi MG. Review article: irritable bowel syndrome. Aliment Pharmacol Ther 1997;11:3-15.

17. Ivey K. Are anticholinergics of use in the irritable colon syndrome? Gastroenterology 1975;68:1300-7.

18. Poynard T, Naveau S, Mory B, Chaput J. Meta-analysis of smooth muscle relaxants in the treatment of irritable bowel syndrome. Aliment Pharmacol Ther 1994;8:499-510.

19. De Ponti F, Giaroni C, Cosentino M, Lecchini S, Frigo GM. Calcium-channel blockers and gastrointestinal motility: basic and clinical aspects. Pharmacol Ther 1993;60:121-48.

20. Perez Mateo M, Sillero C, Cuesta A, et al. Diltiazem in the treatment of the irritable bowel syndrome. Int J Clin Pharmacol Res 1986;6:425-7.

21. Onghena P, Houdenhove BV. Antidepressant-induced analgesia in chronic non-malignant pain: a meta-analysis of 39 placebo-controlled studies. Pain 1992;49:205-19.

22. Clouse RE, Lustman PJ, Geisman RA, Alpers DH. Antidepressant therapy in 138 patients with irritable bowel syndrome: A five-year clinical experience. Aliment Pharmacol Ther 1994;8:409-16.

23. Müller-Lissner S. Effect of wheat bran on weight of stool and gastrointestinal transit time: a meta analysis. Br Med J 1988;296:615-7.

24. Scarpignato C. Pharmacological stimulation of gastrointestinal motility: where we are and where are we going? Dig Dis 1997;15(Suppl 1):112-36.

25. Schuurkes JAJ. Facilitation of acetylcholine release via serotonin receptors: effect of cisapride? In: Heading RC, Wood JD, eds. Gastrointestinal Dysmotility: Focus on Cisapride. New York: Raven Press, 1992:107-15.

26. Wiseman LR, Faulds D. Cisapride. An updated review of its pharmacology and therapeutic efficacy as a prokinetic agent in gastrointestinal motility disorders. Drugs 1994;47:116-52.

27. Passaretti S, Tittobello A, Capozzi C, Verlinden M. Cisapride accelerates total intestinal transit in patients with irritable bowel syndrome-associated constipation. Prog Med 1987;43 (Suppl 1):121-9.

28. Van Outryve M, Milo R, Toussaint J, et al. "Prokinetic" treatment of constipation-predominant irritable bowel syndrome: a placebo-controlled study of cisapride. J Clin Gastroenterol 1991;13:49.

29. Schütze K, Brandstatter G, Dragosics B, Judmaier G, Hentschel E. Double-blind study of the effect of cisapride on constipation and abdominal disconfort as components of the irritable bowel syndrome. Aliment Pharmacol Ther 1997;11:387-94.

30. Awouters F, Megens A, Verlinden M, Schuurkes J, Niemegeers C, Janssen PA. Loperamide. Survey of studies on mechanism of its antidiarrheal activity. Dig Dis Sci 1993;38:977-95.

31. Cann PA, Read NW, Holdsworth CD, Barends D. Role of loperamide and placebo in management of irritable bowel syndrome (IBS). Dig Dis Sci 1984;29:239-47.

32. Lavo B, Stenstam M, Nielsen AL. Loperamide in treatment of irritable bowel syndrome - a-double blind placebo controlled study. Scand J Gastroenterol 1987;32(Suppl 130):81. (Abst)

33. Havdenak N. Loperamide treatment of the irritable bowel syndrome. Scand J Gastroenterol 1987;32(Suppl 130):81. (Abst)

34. Talley NJ, Phillips SF, Haddad A, et al. GR 38082F (Ondansetron), a selective $5-\mathrm{HT}_{3}$ receptor antagonist, slows colonic transit in healthy man. Dig Dis Sci 1990;35:477-80.

35. Talley N. Review article: 5-hydroxytryptamine agonists and antagonists in the modulation of gastrointestinal motility and sensation: clinical implications. Aliment Pharmacol Ther 1992;6:273-89.

36. Maxton D, Haigh C,Whorwell P. 5-HT 3 antagonists: a role in irritable bowel syndrome and non-ulcer dyspepsya? Gut 1991;32:A1228. (Abst)

37. Steadman C, Talley N, Phillips S, et al. Selective 5-hydroxytryptamine type 3 receptor antagonism with ondasetron as treatment for diarrhea-predominant irritable bowel syndrome: a pilot study. Mayo Clin Proc 1992;67:732-8.

38. Morisset J, Geoffrion L, Larose L, et al. Distribution of muscarinic receptors in the digestive tract organs. Pharmacology 1986;22:189-95.

39. Eglen RM, Hegde SS, Watson N. Muscarinic receptor subtypes and smooth muscle function. Pharmacol Rev 1996;48:531-65.

40. Lepor H, Rigaud G, Shapiro E, Baumann M, Kodner IJ, Fleshman JW. Muscarinic cholinergic and alpha-2-adrenergic receptors in the epithelium and muscularis of the human ileum. Surgery 1990;107:461-7.

41. Kerr PM, Hillier K, Wallis RM, Garland CJ. Characterization of muscarinic receptors mediating contractions of circular and longitudinal muscle of human isolated colon. Br J Pharmacol 1995;115:1517-24.

42. Gomez A, Martos F, Bellido I, et al. Muscarinic receptor subtypes in human and rat colon smooth muscle. Biochem Pharmacol 1992;43:2413-9.

43. Kopp R, Lambrecht G, Mutschler E, Moser U, Tacke R, Pfeiffer A. Human HT-29 colon carcinoma cells contain muscarinic $M_{3}$ receptors coupled to phosphoinositide metabolism. Eur J Pharmacol 1989;172:397-405.

44. Thomas EA, Baker SA, Ehlert FJ. Functional role for the $M_{2}$ muscarinic receptor in smooth muscle of guinea pig ileum. Mol Pharmacol 1993;44:102-10.

45. Reddy H, Watson N, Ford APDW, Eglen RM. Characterization of the 
muscarinic $\mathrm{M}_{2}$ receptors and beta-adrenoceptor

subtypes in guinea-pig isolated ileum. Br J Pharmacol 1995;114:49-56.

46. Eglen RM, Reddy H, Watson N, Challis RAJ. Muscarinic acetylcholine receptor subtypes in smooth muscle. Trends Pharmacol Sci 1994;15:114-9.

47. Wallis RM. Pre-clinical and clinical pharmacology of selective muscarinic $M_{3}$ receptor antagonists. Life Sci 1995;56:861-8.

48. Alabaster VA. Discovery and development of selective $\mathrm{M}_{3}$ antagonists for clinical use. Life Sci 1997;60:1053-60.

49. Feinberg M. The problems of anticholinergic adverse effects in older patients. Drugs Aging 1993;3:335-48.

50. Houghton LA, Rogers J, Whorwell PJ, Campbell FC, Williams NS, Goka J. Zamifenacin (UK-76,654), a potent gut $\mathrm{M}_{3}$ selective muscarinic antagonist, reduces colonic motor activity in patients with irritable bowel syndrome. Aliment Pharmacol Ther 1997;11:561-8.

51. Micheletti R, Schiavone A, Giachetti A. Muscarinic M receptors stimulate a nonadrenergic noncholinergic inhibitory pathway in the isolated rat duodenum. J Pharmacol Exp Ther 1988;244:680-4.

52. Schiavone A, Sagrada A, Micheletti R, Giachetti A. Pharmacological characterization of muscarinic receptors involved in $\mathrm{McN}-\mathrm{A}-343$ induced effects on intestinal motility and heart rate in conscious dogs. Br J Pharmacol 1988;94:566-72.

53. Hakonarson H, Herrick DJ, Grunstein MM. Mechanism of impaired beta-adrenoceptor responsiveness in atopic sensitized airway smooth muscle. Am J Physiol 1995;269:L645-52.

54. Bayliss WM, Starling EH. The movements and innervation of the small intestine. J Physiol (Lond) 1899;24:99-143.

55. McIntyre AS, Thompson DG. Review article: Adrenergic control of motor and secretory function in the gastrointestinal tract. Aliment Pharmacol Ther 1992;6:125-42.

56. De Ponti F, Garoni C, Cosentino M, Lecchini S, Grigo GM. Adrenergic mechanisms in the control of gastrointestinal motility: from basic science to clinical applications. Pharmacol Ther 1996;69:59-78.

57. Emorine L, Blin N, Strosberg AD. The human $\beta_{3}$-adrenoceptor: the search for a physiological function. Trends Pharmacol Sci 1994;15:3-7.

58. Manara L, Croci T, Landi M. $\beta_{3}$-adrenoceptors and intestinal motility. Fundam Clin Pharmacol 1955;9:332-42.

59. De Ponti F, Gibelli G, Croci T, Arcidiaco M, Crema F, Manara L. Functional evidence of atypical $\beta_{3}$-adrenoceptors in the human colon using the beta-3-selective adrenoceptor antagonist, SR 59230A. Br J Pharmacol 1996;117:1374-6.

60. Krief S, Lonnqvist F, Raimbault S, et al. Tissue distribution of $\beta_{3}$-adrenergic receptor mRNA in man. J Clin Invest 1993;91:344-9.

61. Berkowitz DE, Nardone NA, Smiley RM, et al. Distribution of $\beta_{3}$-adrenoceptor mRNA in human tissues. Eur J Pharmacol 1995;289:223-8.

62. Howe R. $\beta_{3}$-adrenergic agonists. Drugs Future 1993;18:529-49.

63. Giudice A, Croci T, Bianchetti A, Manara L. Inhibition of rat colonic motility and cardiovascular effects of new gut-specific beta-adrenergic phenylethanolaminotetralines. Life Sci 1989;44:1411-7.

64. De Ponti F, Cosentino M, Costa A, et al. Inhibitory effects of SR 58611A on canine colonic motility: Evidence for a role of beta-3-adrenoceptors. Br J Pharmacol 1995;114:1447-53.

65. Delvaux M, Louvel D, Peronnet P, Bouloux C, Frexinos J. Effect of SR $58611 \mathrm{~A}$, an agonist at the adrenergic beta-3 receptor, on rectal sensory thresholds in healthy volunteers. Gastroenterology 1995;108:A589. (Abst)

66. Holzer P, Holzer-Petsche U. Tachikinins in the Gut. Part I. Expression, release and motor function. Pharmacol Ther 1977;73:173-217.

67. Guard S, Watson SP. Takchykinin receptor types: classification and membrane signaling mechanisms. Neurochem Int 1991;18:149-65.

68. Maggi CA. The mammalian tackykinin receptors. Gen Pharmacol 1995;26:911-44.

69. Holzer-Petsche U. Tachikinin receptors in gastrointestinal motility. Regul Peptides 1995;57:19-42.

70. Gates TS, Zimmerman RP, Mantyh CR, et al. Substance P and substance $\mathrm{K}$ receptor binding sites in the human gastrointestinal tract: localization by autoradiography. Peptides 1988;9:1207-19.

71. Maggi CA, Patacchini R, Santicioli P, et al. Human isolated small intestine: motor response of the longitudinal muscle to field stimulation and exogenous neuropeptides. Naunyn Schmiedebergs Arch Pharmacol 1989;339:415-23.
72. Maggi CA, Patacchini R, Santicioli P, et al. Human isolated ileum: motor responses of the circular muscle to fied stimulation and exogenous neuropeptides. Naunyn Schmiedebergs Arch Pharmacol 1990;341:256-61.

73. Giuliani S, Barbanti G, Turini D, et al. $\mathrm{NK}_{2}$ tachykinin receptors and contraction of circular muscle of the human colon: characterization of the $\mathrm{NK}_{2}$ receptor subtype. Eur J Pharmacol 1991;203:365-70.

74. Kölbel CB, Mayer EA, Holtmann G, et al. Effects of neurokinins on human colonic motility. Neurogastroenterol Motil 1994;6:119-27.

75. Croci T, Aureggi G, Manara L, et al. Functional neurotensin and tachykinin $\mathrm{NK}_{2}$ receptors in human colon strips. Gastroenterology 1997;112:A716. (Abst)

76. Korman LY, Sayadi H, Bass B, Moody TW, Harmon JW. Distribution of vasoactive intestinal polypeptide and substance $P$ receptors in human colon and small intestine. Dig Dis Sci 1989;34:1100-8.

77. Holzer P, Holzer-Petsche U. Tachykinins in the gut. Part II. Roles in neural excitation, secretion and inflammation. Pharmacol Ther 1997;73:219-63.

78. Maggi CA, Patacchni R, Rovero P, Giachetti A. Tachykinin receptors and tachykinin receptor antagonists. J Auton Pharmacol 1993;13:23-93.

79. Tramontana M, Maggi CA, Evangelista S. Spasmolytic effect of the $\mathrm{NK}_{2}$-receptor-selective antagonist MEN-10,627 in rat small intestine. Jpn J Pharmacol 1994;65:281-3.

80. Croci T, Emonds Alt X, Manara L. SR 48968 selectively prevents faecal excretion following activation of tachykinin $\mathrm{NK}_{2}$ receptors in rats. J Pharm Pharmacol 1994;46:383-5.

81. Emonds Alt X, Advenier C, Soubrie P, Le Fur C, Breliere JC. SR 48968: non peptide antagonist of the tachykinin NK2-receptor. Drugs Future 1995;20:701-7.

82. Quartara L, Rovero P, Maggi CA. Peptide-based tachykinin $\mathrm{NK}_{2}$ receptor antagonists. Med Res Rev 1995;15:139-55.

83. Godfraind T, Miller R, Wibo M. Calcium antagonism and calcium entry blockade. Pharmacol Rev 1986;38:321-416.

84. Pietrobon D, Di Virgilio F, Pozzan T. Structural and functional aspects of calcium homeostasis in eukaryotic cells. Eur J Biochem 1990;193:599-622.

85. Yoshino M, Someya T, Nishio A, Yabu H. Whole-cell and unitary Ca channel currents in mammalian intestinal smooth muscle cells: evidence for the existence of two types of Ca channels. Pflügers Arch 1988;411:229-31.

86. Ahmad S, Rausa J, Jang E, Daniel EE. Calcium channel binding in nerves and muscle of canine small intestine. Biochem Biophys Res Commun 1989;159:119-25.

87. Spedding M, Paoletti R. Classification of calcium channels and sites of action of drugs modifying channel function. Pharmacol Rev 1992;44:363-7.

88. Lecchini S, Marcoli M, De Ponti F, Castelletti CA, Frigo GM. Selectivity of $\mathrm{Ca}^{2+}$ channel blockers in inhibiting muscular and nerve activities in isolated colon. Br J Pharmacol 1991;102:735-41.

89. Donowitz M, Levin S, Powers G, et al. $\mathrm{Ca}^{2+}$ channel blockers stimulate ileal and colonic water absorption. Gastroenterology 1985;89:858-66.

90. Findling R, Frishman W, Javed MT, Heffer S, Brandt L. Calcium channel blockers and the gastrointestinal tract. Am J Ther 1996;3:383-408.

91. De Ponti F, Giaroni C, Cosentino M, Lecchini S, Frigo G. Calcium-channel blockers and gastrointestinal motility: basic and clinical aspects. Pharmacol Ther 1993;60:121-48.

92. Narducci F, Bassotti G, Gaburri M, et al. Nifedipine reduces the colonic motor response to eating in patients with the irritable colon syndrome. Am J Gastroenterol 1985;80:317-9.

93. Prior A, Harris SR, Whorwell PJ. Reduction of colonic motility by intravenous nicardipine in irritable bowel syndrome. Gut 1987;28:1609-12.

94. Blume M, Schuster M, Tucker H. Effect of nifedipine on colonic motility in irritable bowel syndrome. Gastroenterology 1983;84:1109A. (Abst)

95. Sun WM, Edwards CA, Prior A, Rao SSC, Read NW. Effect on oral nicardipine on anorectal function in normal human volunteers and patients with irritable bowel syndrome. Gut 1990;35:885-90.

96. Beech DJ, MacKenzie I, Bolton TB, Christen MO. Effects of pinaverium on voltage-activated calcium channel currents of single smooth muscle cells isolated from the longitudinal muscle of the rabbit jejunum. Br J Pharmacol 1990;99:374-8. 
97. Christen MO. Pinaverium bromide: a calcium antagonist with selectivity for the gastrointestinal tract. Today Ther Trends 1995; 13:47-62.

98. Fioramonti J, Frexinos J, Staumont G, Bueno L. Inhibition of the colonic motor response to eating by pinaverium bromide in irritable bowel syndrome patients. Fund Clin Pharmacol 1988;2:19-27.

99. Passaretti S, Sorghi M, Colombo E, Mazzotti G, Tittobello A, Guslandi M. Motor effects of locally administered pinaverium bromide in the sigmoid tract of patients with irritable bowel syndrome. Int J Clin Pharmacol Ther Toxicol 1989;27:47-50.

100. Pace F, Coremans G, Dapoigny M, et al. Therapy of irritable bowel syndrome - An overview. Digestion 1995;56:433-42.

101. Froguel E, Chaussade S, Roche H, Fallet M, Couturier D, Guerre J. Effects of an intestinal smooth muscle calcium channel blocker (pinaverium bromide) on colonic transit time in humans. J Gastrointest Motil 1990;2:176-9.

102. Maggi CA, Manzini S, Meli A. Octylonium bromide: a smooth muscle relaxant which interferes with calcium ions mobilization. Arch Int Pharmacodyn Ther 1983;264:305-23.

103. Gandia L, Lopez MG, Villarroya M, et al. Blocking effects of otilonium on $\mathrm{Ca}^{2+}$ channels and secretion in rat chromaffin cells. Eur J Pharmacol 1996;298:199-205.

104. Capurso L, Tarquini M, Casini A, Formica N, Mannucci C, Perico A. Plasma pharmacokinetics of $300 \mathrm{mg}$ of octylonium bromide solution after endoscopic application. Curr Ther Res 1991;50:539-45.

105. Amenta F, Baroldi P, Ferrante F, Napoleone P, Meli A. Autoradiographic localization of octylonium bromide binding sites in the rat gastrointestinal tract. Arch Int Pharmacodyn Ther 1991;311:5-19.

106. Grider JR. Role of cholecystokinin in the regulation of gastrointestinal motility. J Nutr 1994;124(8 Suppl):1334S-9S.

107. Snape WJ, Materazzo SA, Cohen S. Effect of eating and GI hormones on human colonic myoelectrical and motor activity. Gastroenterology 1978; $75: 373-8$

108. Fossati-Marchal S, Coffin B, Flourié B, et al. Effects of cholecystokinin octapeptide (CCK-OP) on the tonic and phasic motor activity of the human colon. Gastroenterology 1994;106:A499. (Abst)

109. Niederau C, Faber S, Karaus M. Cholecystokinin's role in regulation of colon motility in health and in irritable bowel syndrome. Gastroenterology 1992;102:1889-98.

110. O'Brien MD, Camilleri M, Thomforde GM, Wiste GM, Hanson RB, Zinsmeister AR. Effect of cholecystokin octapeptide and atropine on human colonic motility, tone, and transit. Dig Dis Sci 1997;42:26-33.

111. Scarpignato C. Cholecystokinin antagonists and motilides: pharmacology and potential in the treatment of gastroesophageal reflux disease and other digestive motor disorders. Front Gastrointest Res 1992;20:90-128.

112. Boden P, Hall MD, Hughes J. Cholecystokinin receptors. Cell Mol Neurobiol 1995;15:545-59.

113. Wank SA. Cholecystokinin receptors. Am J Physiol 1995;269:G628-46.

114. D'Amato M, Rovati LC. Cholecystokinin-A receptor antagonists: therapies for gastrointestinal disorders. Exp Opin Invest Drugs 1997;6:819-36

115. Meyer BM, Werth BA, Beglinger C, et al. Role of cholecystokinin in regulation of gastrointestinal motor functions. Lancet 1989;ii:12-5.

116. Meier R, D'Amato M, Pullwitt A, Schneider H, Rovati LC, Beglinger C. Effect of a $\mathrm{CCK}_{\mathrm{A}}$ receptor antagonist in an experimental model of delayed colonic transit time in man. Gastroenterology 1994;106:A538. (Abst)

117. Meier R, Beglinger C, Giacovelli G, D'Amato M. Effect of the CCK-A receptor antagonist dexloxiglumide on postprandial gallbladder emptying and colonic transit time in healthy volunteers. Gastroenterology 1997;112:A788. (Abst)

118. Meier R, Beglinger C, Thurmshirn M, et al. Therapeutic effects of loxiglumide, a cholecystokinin antagonist, on chronic constipation in elderly patients, a prospective, randomised, double-blinded, controlled trial. J Gastrointest Motil 1993;5:129-35.

119. Renny A, Snape WJ, Sun E, London R, Cohen S. Role of cholecystokinin in the gastrocolic response to a fat meal. Gastroenterology 1983;85:17-21.

120. Jehle EC, Blum AL, Fried M. Role of cholecystokinin in the regulation of basal colonic motility and the gastrocolic response. Gastroenterology 1990;98:A361. (Abst)

121. Mayer EA, Raybould HE. Role of visceral afferent mechanisms in functional bowel disorders. Gastroenterology 1990;99:1688-704. provoked by stimuli in the irritable bowel syndrome. Gut 1988;29:1236-43.

123. Harvey RF, Read AE. Effect of cholecystokinin on colonic motility and symptoms in patients with the irritable bowel syndrome. Lancet 1973;i:1-3.

124. Roberts-Thomson IC, Fettman MJ, Jonsson JR, Frewin DB. Responses to cholecystokinin octapeptide in patients with functional abdominal pain syndromes. J Gastroenterol Hepatol 1992;7:293-7.

125. Sjolund K, Ekman R, Lindgren S, Rehfeld JF. Disturbed motilin and cholecystokinin release in the Irritable Bowel Syndrome. Scand J Gastroenterol 1996;31:1110-4.

126. Cann PA, Rovati LC, Smart H, Spiller RC, Whorwell PJ. Loxiglumide a CCK-A antagonist, in irritable bowel syndrome: a pilot multicentre clinical study. Ann NY Acad Sci 1994;23:449-50.

127. Barrow L, Blackshaw PE, Wilson CG, Rovati L, Spiller RC. Selective slowing of proximal colon transit in irritable bowel syndrome by the cholecystokinin-receptor antagonist, loxiglumide. Eur J Gastroenterol Hepatol 1994;6:381-7.

128. McIntosh CHS, Brown JC. Motilin: isolation, secretion, actions and pathophysiology. Front Gastrointest Res 1990;17:307-52.

129. Hasler WL, Heldsinger A, Owyang C. Erythromycin contracts rabbit colon myocytes via occupation of motilin receptors. Am J Physiol 1992;262:G50-5.

130. Sakai T, Satoh M, Sonobe K, Nakajima M, Shiba Y, Itoh Z. Autoradiographic study of motilin binding sites in the rabbit gastrointestinal tract. Regul Peptides 1994;53:249-57.

131. Peeters T. Erythromycin and other macrolides as prokinetic agents. Gastroenterology 1993;105:1886-99.

132. Tomomasa T, Kuruome T, Arai H. Erythromycin induces migrating motor complex in human gastrointestinal tract. Dig Dis Sci 1986;31:157-61.

133. Kondo Y, Torii K, Itoh Z. Erythromycin and its derivatives with motilin-like biological activities inhibit the specific binding of ${ }^{125} \mathrm{I}$-motilin to duodenal muscle. Biochem Biophys Res Commun 1988; 150:877-82.

134. Peeters T, Matthijs G, Depoortere I. Erythromycin is a motilin receptor agonist. Am J Physiol 1989;257:G470-4.

135. Costa A, De Ponti F, Gibelli G, Crema F, D’Angelo L. In vivo characterization of the colonic prokinetic effect of erythromycin in the rabbit. Pharmacology 1977;54:64-7.

136. Bradette M, Poitras P, Boivin M. Effect of motilin and erythromycin on the motor activity of the human colon. J Gastrointest Motil 1993;5:247-51.

137. Jameson JS, Roger J, Misiewicz JJ, Raimundo AH, Henry MM. Oral or intravenous erythromycin has no effect on human distal colonic motility. Aliment Pharmacol Ther 1992;6:589-95.

138. Bassotti G, Betti C, Imbimbo BP, Pelli MA, Morelli A. Erythromycin and edrophonium chloride do not stimulate colonic propagated activity in chronically constipated subjects. Gastroenterology 1991;100:A419. (Abst)

139. Lehtola J, Jauhonen P, Kesaniemi A, Wikberg R, Gordin A. Effect of erythromycin on the oro-caecal transit time in man. Eur J Clin Pharmacol 1990;39:555-8.

140. Landry C, Vidon N, Sogni P, et al. Effects of erythromycin on gastric emptying, duodeno-caecal transit time, gastric and biliopancreatic secretion during continuous gastric infusion of a liquid diet in healthy volunteers. Eur J Gastroenterol Hepatol 1995;7:797-802.

141. Minocha A, Gallo SH. Effect of erythromycin on orocecal transit time in normal healthy male subjects: a double-blind placebo controlled study. Can J Gastroenterol 1995;9:195-8.

142. Ueberschaer B, Ewe K, Alles U, Schmidtmann I. Effect of $4 \times 250 \mathrm{mg}$ erythromycin on human gastrointestinal transit. Z Gastroenterol 1995;33:340-4.

143. Minami T, Nishibayashi H, Shinomura Y, Matsuzawa Y. Effects of erythromycin in chronic idiopathic intestinal pseudo-obstruction. J Gastroenterol 1996;31:855-9.

144. Sharma SS, Bhargava N, Mathur SC. Effect of oral erythromycin on colonic transit in patients with idiopathic constipation. A pilot study. Dig Dis Sci 1995;40:2446-9.

145. Minocha A, Katragadda R, Rahal PS, Ries A. Erythromycin shortens orocaecal transit time in diabetic male subjects: A double-blind placebo-controlled study. Aliment Pharmacol Ther 1995;9:529-33.

146. Hasler A, Heldsinger A, Soudah H, Owyang C. Erythromycin promotes colonic transit in humans: mediation via motilin receptors. Gastroenterology 1990;98:A358. (Abst) 
147. Sharma SS, Bhargava N, Mathur SC. Effect of oral erythromycin on colonic transit in patients with idiopathic constipation. A pilot study. Dig Dis Sci 1995;40:2446-9.

148. Omura S, Tsuzuki K, Sunazuka T, et al. Macrolides with gastrointestinal motor stimulating activity. J Med Chem 1987;30:1941-3.

149. Itoh Z, Omura S. Motilides, a new family of macrolide compounds mimicking motilin. Dig Dis Sci 1987;32:915.

150. Read NW, Gwee KA. The importance of 5-hydroxytryptamine receptors in the gut. Pharmacol Ther 1994;62:159-73.

151. Talley NJ. Review article: 5 -hydroxytryptamine agonists and antagonists in the modulation of gastrointestinal motility and sensation: clinical implications. Aliment Pharmacol Ther 1992;6:273-89.

152. Costall B, Naylor RJ. 5-hydroxytryptamine: new receptors and novel drugs for gastrointestinal motor disorders. Scand J Gastroenterol 1990;25:769-87.

153. Fernandez AG, Massingham R. Peripheral receptor populations involved in the regulation of gastrointestinal motility and the pharmacological actions of metoclopramide-like drugs. Life Sci $1985 ; 36: 1-14$

154. Fozard JR. 5-HT 3 receptors and cytotoxic drug-induced vomiting. Trends Pharmacol Sci 1987;8:44-5.

155. Eglen RM, Hegde SS. 5-hydrotryptamine (5-HT) ${ }_{4}$ receptors: physiology, pharmacology and therapeutic potential. Exp Opin Invest Drugs 1996;5:373-88.

156. Tonini M. Recent advances in the pharmacology of gastrointestinal prokinetics. Pharmacol Res 1996;33:217-26.

157. Tam FS F, Hillier K, Bunce KT. Characterization of the 5-hydroxytryptamine receptor type involved in inhibition of spontaneous activity of human isolated colonic circular muscle. Br J Pharmacol 1994;113:143-50.

158. Schuurkes JAJ, Meulemans AL, Obertop H, Akkermans LMA. 5HT receptors on the human stomach. J Gastrointest Motil 1991;3:1-19.

159. Burleigh DE, Trout SJ. Evidence against an acetylcholine releasing
PINC, DO NOT COPY 1995;20:475-8.

160. Borman RA, Burleigh DE. Evidence for the involvement of a $5-\mathrm{HT}_{4}$ receptor in the secretory response of human small intestine. Br J Pharmacol 1993;110:927-8.

161. Briejer MR, Ghoos Y, Eelen J, Schuurkes JAJ. Serotonin $5 \mathrm{HT}_{4}$ receptors mediate the R-093877-induced changes in contractile patterns in the canine colon. Gastroenterology 1997;112:A705. (Abst)

162. Poen AC, Felt-Bersma RJF, Meuwissen SGM. A placebo controlled study to evaluate the effects of repeated oral doses of R-093877 on gastrointestinal transit and anorectal manometry in healthy volunteers. Gastroenterology 1997;112:A807. (Abst)

163. Büchheit KH, Gamse R, Giger R, et al. The serotonin 5-HT-4 receptor. 2. Structure - Activity studies of the indole carbazimidamide class of agonist. J Med Chem 1995;38:2331-8.

164. Ormsbee HS, Koehler SI, Telford GL. Somatostatin inhibits motilin-induced interdigestive contractile activity in the dog. Dig Dis Sci 1978;23:781-8.

165. Hostein J, Janssens J, Vantrappen G, Peters T, Vandeweerd M, Leman G. Somatostatin induces ectopic activity fronts of the migrating motor complex via a local intestinal mechanism. Gastroenterology 1984;87:1004-8.

166. Soudah HC, Hasler WL, Owyang C. Effect of octreotide on intestinal motility and bacterial overgrowth in scleroderma. N Engl J Med 1991;325:1461-7.

167. Scarpignato C. Octreotide, the synthetic long-acting somatostatin analogue: pharmacological profile. Prog Basic Clin Pharmacol 1995;10:54-72.

168. Haruma K, Wiste JA, Camilleri M. Effect of octreotide on gastrointestinal pressure profiles in health and in functional and organic gastrointestinal disorders. Gut 1994;35:1064-9.

169. Van der Ohe MR, Camilleri M, Thomforde GM, Klee GG. Differential regional effects of octreotide on human gastrointestinal motor function. Gut 1995;36:743-8. 


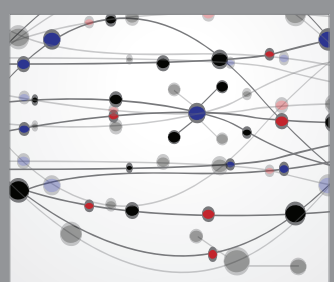

The Scientific World Journal
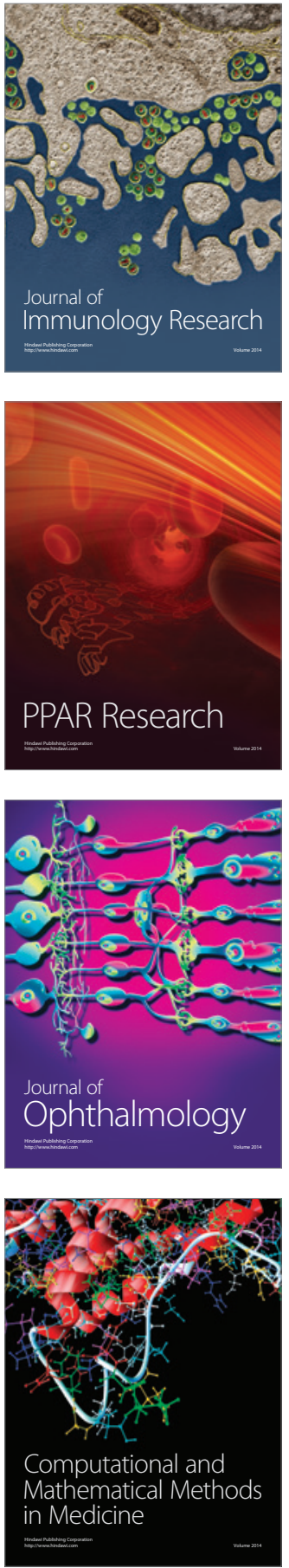

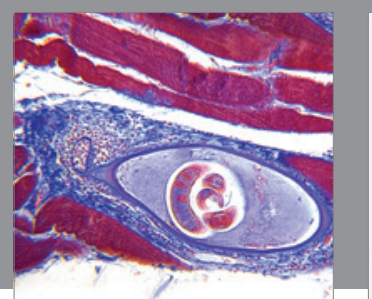

Gastroenterology Research and Practice

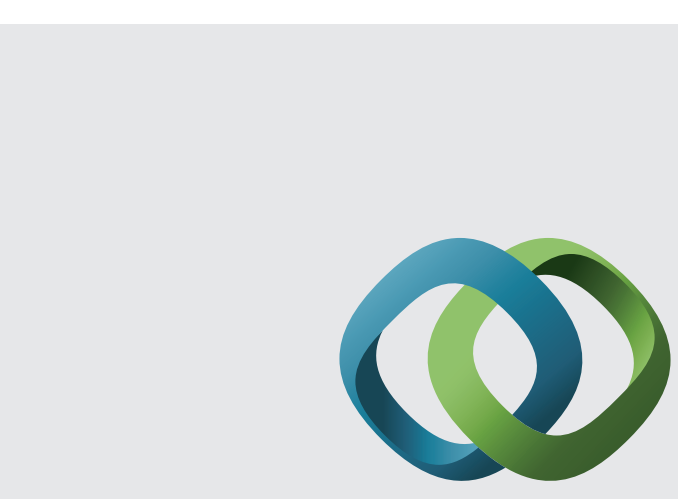

\section{Hindawi}

Submit your manuscripts at

http://www.hindawi.com
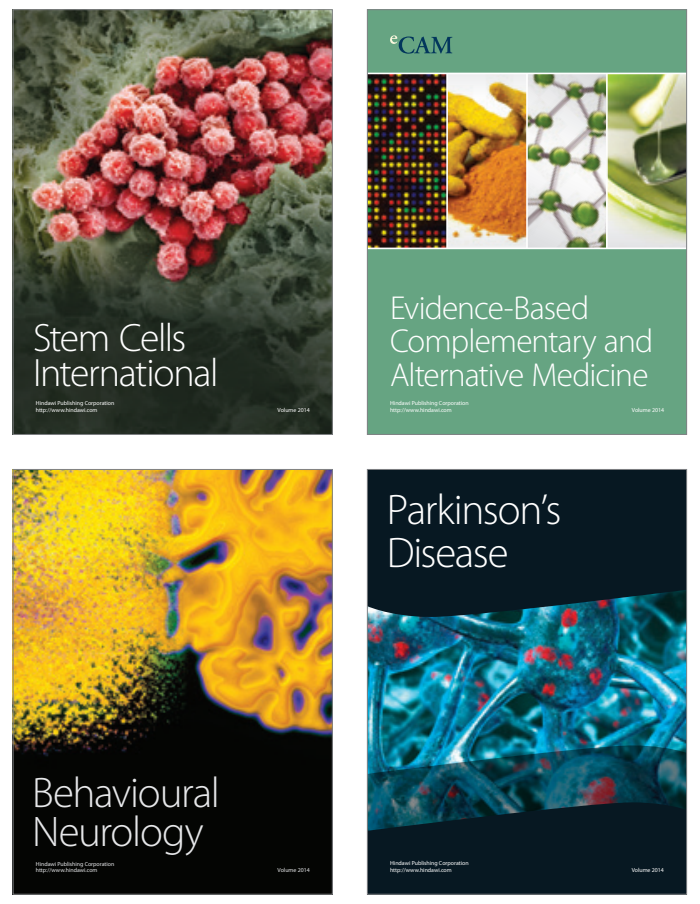
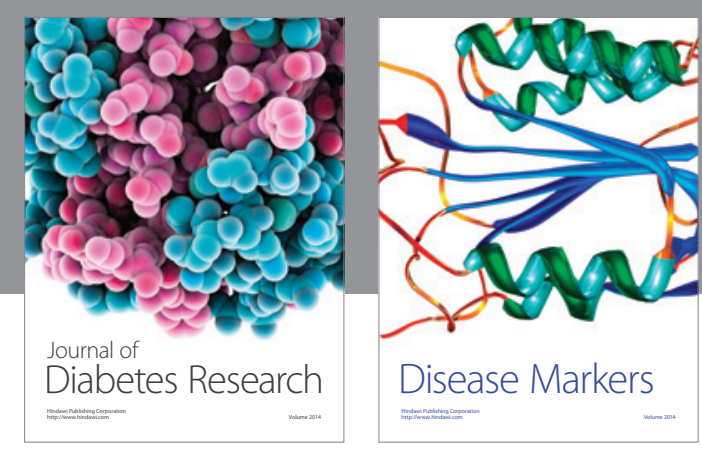

Disease Markers
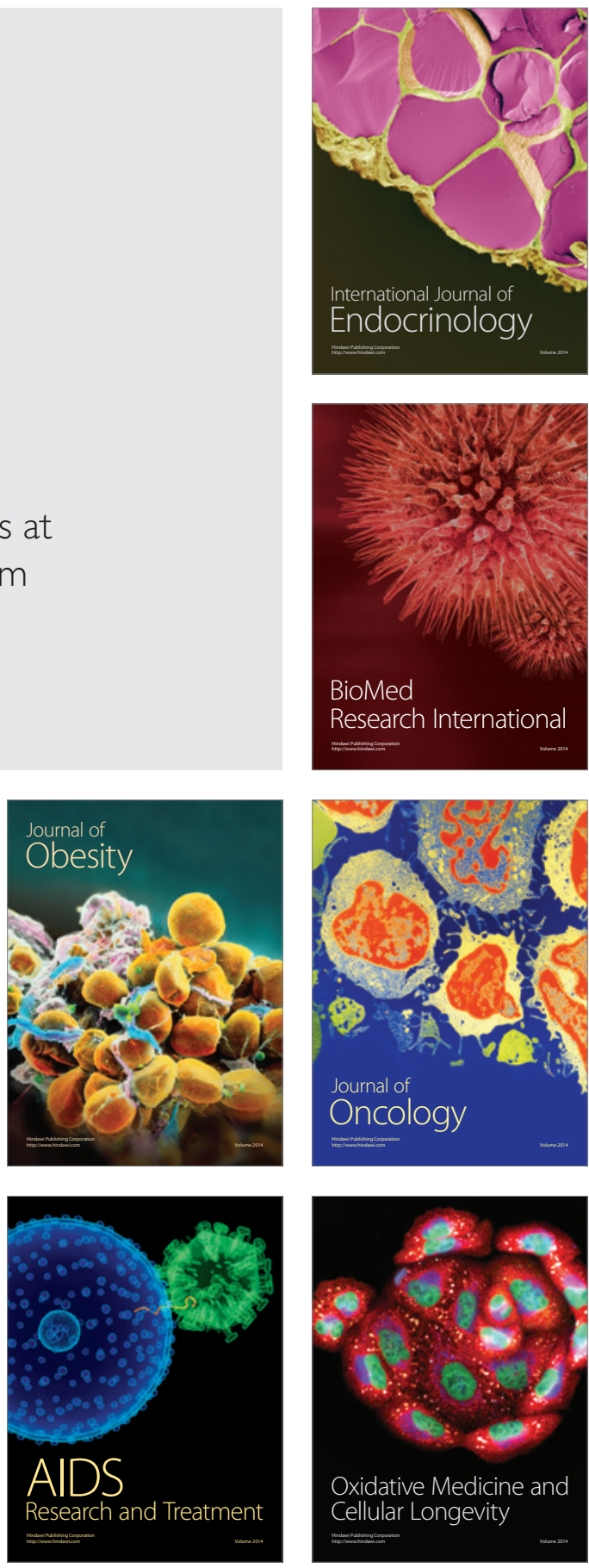